\title{
A administração da diferença: materialidade e poder na constituição dos espaços, territórios e estruturas temporais na constituição de um programa de pesquisa ${ }^{1}$
}

\author{
The administration of difference: materiality and power \\ in the constitution of spaces, territories and temporal \\ structures in the constitution of a research program
}

\begin{abstract}
Bernardo Curvelano Freire
Universidade Federal do Vale do São Francisco campus de São Raimundo Nonato, PI

Pesquisador do Laboratório em Metodologia, Pesquisa e Documentação em Antropologia (LaMPDA) refratordecurvelo@gmail. com
\end{abstract}

Recebido em 11/09/2018 Aceito em 25/11/2018
Dois bancos existem no Tiergarten, um verde, como de costume, e outro amarelo (os judeus, então, só podiam sentar-se em bancos amarelos), e entre os dois há um cesto para papel. Sento-me no cesto e eu mesmo penduro no pescoço um letreiro, como fazem por vezes os mendigos cegos e como também as autoridades obrigam os 'violadores da raça' a fazer: 'Se for necessário, deixarei lugar para o papel'"

da coleção de sonhos da época do Terceiro Reich, editada por Charlotte Beradt

O encontro com outrem consiste no fato de que, apesar da extensão da minha dominação sobre ele e de sua submissão, não o possuo. Ele não entra na abertura do sem em que já me encontro como no campo de minha liberdade. Não é a partir do ser em geral que ele vem ao meu encontro. Tudo o que dele me vem a partir do ser em geral se oferece por certo à minha compreensão e posse. Compreendo-o, a partir de sua história, do seu meio, de seus hábitos. O que nele escapa à minha compreensão é ele, o ente. Não posso negá-lo parcialmente, na violência, apreendendo-o a partir do ser em geral e possuindo-o. Outrem é o único ente cuja negação não pode anunciar-se senão como total: um homicídio. Outrem é o único ser que posso querer matar.

Emmanuel Lévinas, A ontologia é fundamental?

\section{Resumo}

A noção de administração da diferença que orienta este trabalho, antes especulativo do que propriamente etnográfico, tem como premissa situações sociais muito específicas. É fruto de trabalhos com os quais me envolvi desde que assumi o cargo de professor efetivo do Colegiado de Antropologia no campus de São Raimundo Nonato da Universidade Federal do Vale do São Francisco (CANT-Univasf), no sudeste do Piauí. Estes trabalhos não dizem respeito à atividade de pesquisador propriamente dita, sendo antes fruto de um envolvimento com a vida local, em histórias diversas que incluem a ameaça do advento de uma agenda de mineração predatória conduzida pela atual secretária de Minas, Petróleo e Energias Renováveis do governo de Wellington Dias (PT-PI), as lutas quilombolas por segurança 
Este trabalho jamais teria sido escrito sem as conversas com Antônio Bispo dos Santos e Claudio Teófilo Marques, lideranças quilombola com quem tenho o privilégio de trabalhar pelos últimos dois anos, sempre pacientes e generosos comigo. É pelo respeito que tenho com eles e com as comunidades quilombola que peço licença ao conhecimento avô para publicar parte do conteúdo de nossas conversas. Fábio Antônio da Costa é parceiro antigo das leituras que realizo e me apoiou para que eu escrevesse este artigo. Agradeço também a Nilson Parente, residente do povoado do Novo Zabelê e, também, do antigo Zabelê, quem me introduziu novas dimensões da história territorial da então Serra a Capivara. Por fim, agradeço a Pedro Galdino, outro grande amigo, por ter realizado uma revisão de última hora, fazendo com que meus desvios fossem um pouco menores. territorial e jurídica, políticas acadêmicas que envolvem a complexidade da formação de um curso de graduação em antropologia ao lado das atividades de uma instituição do porte da Fundação Museu do Homem Americano (FUMDHAM), um dos três órgãos que administram o Parque Nacional da Serra da Capivara. Sendo assim, o que escrevo tem muito mais base em envolvimento sistemático do que em levantamento sistemático, o que são duas noções de sistema que não dialogam com a melhor das habilidades. Neste sentido, atentar para a noção de administração da diferença diz respeito tanto à administração das relações que instituem diferenças relevantes em contextos de conflitos diversos, mas sujeitos à uma mediação que transcende à força, quanto à produção de um modo de existência pautado pela sua negação, orientado por indiferença, cujos efeitos são sempre catastróficos. Esta noção leva em consideração eventos em que partes assimétricas em um determinado processo social deliberam a respeito da gestão do espaço a partir da delimitação de um território determinado pela força da lei.

Palavras-chave: Administração da diferença, antropologia, comunidades quilombolas, estruturas temporais

\section{Abstract}

This article steps toward the notion of administration of difference that is, before ethnographic, somehow speculative even as premises some very specific social situations. As so, it is the result of a bunch of different works with which I got around since I became professor at the Anthropology College at Universidade Federal do Vale do São Francisco (UNIVASF), in São Raimundo Nonato, southeast of Piauí. Neither the different projects mentions or questions the researcher's role because they are a directed by getting around by the local communities and their diverse stories that includes 1) the menace expressed by a obscure predatory mining agenda conducted by the present governor's Mine, Oil and Renewable Energy Secretary, conducted by Wellington Dias' (PT-PI) government; 2) the quilombolas struggle for territorial and judicial security; 3 ) research policies that handle the complexity that characterizes the creation of a graduation course in anthropology just beside an institution as big as Museu do Homem Americano Foundation (FUMDHAM), one of the three institutions that administrate the Serra da Capivara National Park. With this in mind, what is writen below is much more based in a systematic engagement than it is in a systematic research, and I know that they are completely different notions of system that does not goes well together. Knowing this, to pay attention to the notion of administration of difference points to, both, the administration of relations that institutes relevant differences in diverse contexts of conflict but subjected to a transcendent by force mediation, as much as points to the production of a mode of existence lined by its own negation, guided by a sort of indifference of which effects are always catastrophic. This notion takes in consideration events in which asymmetrical parts in a determined social process deliberates about the management of space starting with the delimitation of a territory determined by the force of law.

Key words: Administration of Difference, Anthropology, Quilombolas, Temporal Structures. 


\section{Introdução}

Frequentemente, eu faço o esforço de lembrar que vivemos em um país fundado em relações coloniais muito particulares. Suas instituições têm assim um traço de constituição muito peculiar, muito semelhante ao elogio do liberalismo político que frequentemente se esquece de mencionar, se não a exploração das classes trabalhadoras, seguramente o valor estratégico da exploração colonial. Tão distante tanto conceitual quanto fisicamente, tornada um detalhe do percurso normal da curva histórica da civilização, dificilmente está presente em qualquer configuração de qualquer contexto de crise que não seja absolutamente regional. E ainda assim, parece possível sugerir que as relações travadas na área de interesse da colonização, cujo tempo não respeita nenhuma forma de expressão jurídica do seu cessar, especialmente na trama dos amores e desejos entre senhores e escravos, para tomarmos um exemplo de fundação da interpretação do Brasil, gozam de uma espécie perversa de simetria. Dito de outra forma, parece que se as relações afetivas são possíveis, ou se é possível conviver no mundo ordinário da conversação e do compadrio, as relações estariam postas em pé de igualdade ou exercidas em condições simétricas de comunicação. Ora, se é possível imaginar que as fórmulas básicas utilizadas para compreendermos uma certa noção de normalidade, herdeira de uma bibliografia como a produzida por Gilberto Freyre, na qual a ordem patriarcal do Brasil colônia, vista no solo do perspectivismo e, portanto, no corpo que exprime a relação; e se essa mesma bibliografia está atenta ao fato de que gestos simples exprimem violência e assimetria do Brasil colonial, o que dizer de situações em que as relações assimétricas são constitutivas da relação como possibilidade? O que dizer de atos governamentais na produção de território, que são, no universo dos governos representativos, a expressão da assimetria de comunicação?

Importante notar que a assimetria corresponde não somente às diferenças que poderíamos chamar de culturais que frequentemente tencionam divisores cosmológicos de tipo Modernos e Tradicionais, mas institui posições de poder em que as distinções as mais diversas fazem com que a diferença lida por um dos polos da oposição não seja equivalente à mesma oposição vista pelo outro polo, o que faz com que pressupostos de hierarquia e cismogênese de comunicação tenham um lugar privilegiado na comunicação política (VIVEIROS DE CASTRO, 2007). Por sua vez, o poder não está simplesmente na produção de agência, como seria o caso da administração de populações humanas, mais enfaticamente nas práticas de manejo de contingente humano na forma de remoções, reintegrações de posse ou qualquer outro artifício policial de controle do território que, para lembrarmos o adágio melanésio, força a forma. Discutir as formas forçadas de ação política, especialmente aquelas que operam por meio de um enorme contingente midiático que redunda nas formas da esfera pública produzir burocracia, produz um efeito de representação no qual converte ausência em agência que respondem ao signo do procedimento. Dinâmicas processuais que reduzidas a codificações cujo acesso é facultado a um grupo de pessoas ausente dos contextos regionais de disputa política determinam boa parte dos marcos históricos que me servem de anteparo narrativo. Afinal, o tema é administração.

No caso do sudeste do Piauí o procedimento burocrático, ao decidir em ausência e em localidades distantes, ou Teresina-PI, ou em Brasília-DF, significa não somente a distância medida em centenas e milhares de quilômetros, respectivamente, mas nas condições logísticas e financeiras de impedimento de intervenção na cadeia de efeitos que uma decisão burocrática pode produzir. A distância medida pela possibilidade de deslocamento não é a mesma quando lida por sua impossibilidade. Esse efeito desdobra-se do esforço em mobilizar tecnologias políticas de sentido, como ofícios, memorandos, portarias e outras tantas formas de transmissão de sentido documental e da ordem burocrática que afetam as contrapartes da contenda mesmo quando ausentes do debate. Isso indica que a diferença posta para fins de sua administração - afinal, a diferença nunca é abstrata - diz respeito tanto à finalidade da ação, frequentemente justificada pela teoria antropológica pelo aporte ao simbolismo, quanto aos meios de ação, o que nos leva para o terreno da materialidade da comunicação, a infraestrutura do sentido e, de novo, à presença.

A assimetria de meios e fins na gestão de territórios me leva para um segundo problema. No caso, o de que alguém administra a diferença enquanto é, por sua vez, indiferente a ela. Nesse caso torna-se mais visível compreender, em cada acontecimento, como a diferença redunda em desigualdade, uma vez que não 
há igualdade quando não lidamos com poderes da mesma escala. É exatamente essa solução dada por Walter Benjamin (2013) que coloca a mediação jurídica em questão, pois mesmo que favorável aos grupos minoritários, a mesma não pode operar senão deslocando o poder de decisão para a mesma esfera decisória da qual os interesses minoritários não encontram trânsito, ou quando encontram, é em posição mais vulnerável, quando não simplesmente subalterna. Vejamos isso mais de perto.

As pesquisas produzidas com a finalidade de resguardar os direitos territoriais das populações quilombolas no estado do Piauí (MATOS, 2010; SANTOS, 2012) fazem parte de uma geração de pesquisas em antropologia que flertam com a premissa da produção de laudos territoriais cuja missão está em provar a existência de comunidades cuja história remete aos usos tradicionais da terra oriundas da experiência da escravidão para fins de sua administração no compósito territorial que chamamos de território nacional. Essas populações, assim como grande parte as populações tradicionais do interior do espaço territorial brasileiro, viveram séculos de hiato administrativo, ou seja, com parcas documentações a seu respeito, frequentemente imprecisas, estabelecendo assim uma assimetria documental de partida entre o que existe e o que não existe como população. Na busca de corresponder com o artigo 68 (ADCT) da Constituição Federal de 1988', todo o trabalho de regulamentação e identificação de territórios e populações trafega nesse hiato que não é outra coisa senão a própria produção do território nacional. O valor estratégico dessas peças de pesquisa etnográfica está articulado diretamente com o seu limite expresso, a de que a afirmação da existência dos povos está na conversão das experiências colhidas em campo, propriamente convertidas em dados, com vistas principalmente naquilo que é previsto por lei, fazendo com que se busque, antes de mais nada, ajustar as cronologias regionais com a burocracia estatal oficial a fim de localizar essas populações na história política e jurídica nacionais. Esta que parece ser uma crônica das comunidades quilombolas assume um ar mais geral quando mudamos ligeiramente o foco, e trabalhamos com o prisma propriamente quilombola, ao invés de lidarmos com a versão da antropologia a respeito da administração do território piauiense.

Em agosto de 2017 eu tive uma conversa com Antônio Bispo dos Santos, liderança do quilombo Saco/ Curtume em São João do Piauí. O que estava em pauta era a trajetória deste que se tornou uma das principais figuras do movimento quilombola nacional. Como o assunto era a trajetória do próprio Antônio Bispo dos Santos, o Nego Bispo, foi seu papel de liderança que orientava as poucas horas em que conversamos no final de tarde com sua companheira e sua filha de adoção ao redor. O capítulo que nos interessa narra a passagem de Bispo como membro da FETAG-PI², o que compreende o fim dos anos 1980 e meados dos anos 1990. Estávamos na varanda de sua casa e foi a primeira vez, depois de um ano de atividades no território a Serra da Capivara $^{3}$, eu finalmente travava contato com algo de sua trajetória. E foi ouvindo sobre como ele conduziu a primeira ocupação de terras da história do estado, no caso, um terreno da EMBRAPA que seguia até então sem qualquer atividade em meio a uma brutal estiagem, que ouvi algo que, somente ao escrever este artigo, compreendo a gravidade. Após a cadeia de acordos realizados entre EMBRAPA e FETAG, culminando em uma parceria com a finalidade de viabilizar o plantio de feijão e melancia -com festa -, Bispo se vê, em 1994, com a tarefa de rodar o estado do Piauí em busca de trabalhadores rurais assalariados, que o governo do estado do Piauí afirmava não existirem. Nas palavras de Bispo, ele viajou por 15 municípios aplicando um questionário fazendo o diagnóstico e 50 projetos e, assim, acaba fazendo o papel do Estado ao investigar o total desrespeito às condições adequadas para o exercício do trabalho rural. Resultam disso 50 denúncias, todas elas acatadas, servindo de base para primeira convenção rural do estado do Piauí. Estamos em 1994. A CLT data de 1943.

$1 \quad$ Art. 68. Aos remanescentes das comunidades dos quilombos que estejam ocupando suas terras é reconhecida a propriedade definitiva, devendo o Estado emitir-lhes os títulos respectivos.

2 Federação dos Trabalhadores Rurais Agricultores e Agricultoras Familiares do Estado do Piauí, fundada em 19 de dezembro de 1970.

3 É como atualmente o governo do estado nomeia esta área geográfica do estado, que compreende 18 municípios: Bonfim do Piauí, Capitão Gervásio Oliveira, Coronel José Dias, Dom Inocêncio, Lagoa do Barro do Piauí, São João do Piauí, São Raimundo Nonato, Anísio de Abreu, Campo Alegre do Fidalgo, Caracol, Dirceu Arcoverde, Fartura do Piauí, Guaribas, João Costa, Jurema, São Braz do Piauí, São Lourenço do Piauí e Várzea Branca, tem 140.761 habitantes e 3 aglomerados (fonte: https://cidadeverde.com/noticias/243062/territorio-serra-da-capivara-tera-agenda-de-desenvolvimento, site acessado em 7 de setembro de 2018). 
Se virmos o papel assumido pela antropologia como uma das disciplinas encarregadas pela comprovação da existência de outrem, o que vemos tomar forma é a inflação do argumento antropológico, assumindo uma encarnação muito precisa de antropologia nacional, ou seja, a antropologia como carreira de Estado. Essa operação, que não discutirei em maior detalhe aqui, deixa ainda mais evidente a disposição das assimetrias constitutivas da administração da diferença propiciada por atos governamentais, assumidas como necessárias num contexto onde a negação de direitos e a violência no campo constituem-se regra na forma de ocupação do espaço e, também, do tempo. Tal administração da diferença em relações que culminem na configuração de um conflito territorial se manifestam, mesmo que como memória coletiva, nas correlações de força e na precipitação da violência que institui, finalmente, a diferença constitutiva da relação.

O que tenho em mente, ainda que não vá abordar uma bibliografia ostensiva a respeito, são episódios de violação de direitos territoriais e de remoção humana muito pontuais e em um contingente documental precário e deficiente, à luz das afirmações que faço a respeito da estrutura temporal manifesta na materialidade de sua concretização e sua correlação com a letra da lei na produção de pobreza cuja administração é a manifestação da crise como forma. E à letra da lei, a pobreza não aparece na sua forma perceptível, como, aliás, qualquer alusão à experiência, como a moderna tradição jurídica atesta. Assim, confrontar a experiência da violência, da ansiedade, do medo e do terror mediado pela estrutura dos documentos impressos nos leva para um território em que são frequentes os excessos movidos pela interpretação e pela alusão ao simbólico. O que temos, nos casos sobre os quais mal comecei a me debruçar, é a parca existência de documentação disponível que testa a disposição básica da pesquisa em história e em antropologia de buscar uma documentação absolutamente fiável a respeito de eventos traumáticos os quais, acabam por serem convertidos em métodos de governo. Isto nos coloca na posição de assumir como ponto de partida a premissa ética de que a verdade documental não oferece nenhuma hierarquia confiável exatamente pelo seu design. Os processos que registram violências de Estado em suas diversas encarnações, quando discutidos mais atentamente, não figuram como uma exceção à regra jurídica, mas sim na relação em que a instituição de espaços jurídicos tem como fundamento a exceção como instituição da regra. Este tipo de asserção, tendo em vista exatamente a escassez de documentos e relatos que disponho no presente momento, pode soar a exagero. E é. No entanto, o exagero como acesso à estrutura temporal é o tema que trago ao leitor em contrabando

\section{A produção do lugar-nenhum}

Abordar a remoção humana, do povoado do Zabelê, na fundação dos limites do Parque Nacional da Serra da Capivara, São Raimundo Nonato, sudeste do Piauí; abordá-la como episódio da administração da diferença nos termos propostos permite que compreendamos melhor o que entendo como estrutura temporal, conceito que considero chave cuja indefinição promete frustrar o leitor. Isso porque a expulsão do povoado e a fundação dos limites do parque não se dão ao mesmo tempo, e sua crônica indica não somente a ordem burocrática operando na ausência das relações dialógicas presenciais - o que caracteriza o sentido regendo o procedimento legal em detrimento da presença - como também dá visibilidade a um modo de diferença, para todos os efeitos, central: a diferença para a qual a instituição da nova ordem territorial, no caso o Parque, teve que ser indiferente. Esta indiferença mobiliza uma estrutura temporal que inaugura essa nova unidade territorial cuja administração mobiliza diferentes temporalizações - aceleração, suspensão, desaceleração - propiciados pelo Parque que é tanto um ato governamental quanto é um projeto de conservação patrimonial e ambiental; no seu acúmulo infinito, o Parque também é a negação do espaço logo anterior, a territorialidade vigente durante o interflúvio, o tempo entre 1979 e 1988. Este intervalo é, em primeiro lugar, documental e fundamentalmente cronológico, que demarca o tempo de espera entre a criação do Parque e sua inauguração. E o objetivo da pesquisa que começa a tomar forma está no preenchimento desta cronologia, com tantas narrativas de experiência - territorialidade - que o objetivo, ainda que impossível é fazer a cronologia dizer que basta, que não aguenta mais. O que apresento para a leitura corresponde aos meios que pretendo mobilizar para tal. 
O ano de 1979 é o ano do decreto de número 83.548, assinado pelo então presidente João Batista de Figueiredo, no centésimo quinquagésimo oitavo ano da Independência e nonagésimo primeiro ano da República. O decreto foi publicado em 06 de junho do mesmo ano no Diário Oficial, na página 8035 da publicação. Nela aparece a demarcação do Parque Nacional da Serra da Capivara segundo suas coordenadas geográficas, listando os pontos da paisagem da região limítrofe, as linhas telegráficas estabelecendo o território que inaugura, o novo tempo de proteção da flora, da fauna, dos monumentos arqueológicos e das belezas naturais sem determinar quem é o inimigo que ronda. Cabendo notar a suspeitíssima categoria de belezas naturais como objeto de apreciação jurídica, o intervalo entre 1979 e 1988 nos traz um segundo documento que incorpora uma omissão no ato de fundação do Parque, que para fins jurídicos acaba por declará-lo como vazio de tudo que não seja natural. Para fins de administração de reservas, implica dizer que lá nada há que seja político, ainda que muito do que seja humano esteja coberto pela rubrica dos monumentos arqueológicos. O que é político, ou seja, aquilo que é humano e é político ao mesmo tempo - tudo aquilo que pode dizer não -, que se insere em relações contemporâneas ao ato governamental e a inauguração da administração do Parque, está documentado em um documento mimeografado, de ampla circulação, escrito pela antropóloga e historiadora Cristina Pompa. É este único documento que tomo como ponto de partida para uma investigação que se pretende longa e cuidadosa.

Nesse documento, Pompa descreve a instituição do Parque a partir de um conceito muito discutido em antropologia social, no caso, a noção de social drama, cunhado pelo escocês Victor Turner (1920-1983), africanista e produtor de uma vasta discussão sobre rituais, simbolismo e o problema da performance e da experiência. O campo de pesquisas sobre dramas sociais incide neste registro produzido por Cristina Pompa na medida em que ela atenta para o advento do Parque, esta nova unidade territorial, e como o mesmo afeta a dinâmica das relações sociais antes de o Parque acontecer (POMPA, 1987, p. 2), fazendo desta medida administrativa um desencadeamento de efeitos que não estão previstos no ato governamental original. E das coisas que não estavam previstas, encontramos o povoado do Zabelê. Antes de entrarmos em alguns detalhes no ensaio de Cristina Pompa, quero chamar a atenção para algo que considero absolutamente central, alvo de algumas considerações mais adiante. O intervalo cronológico entre o decreto e o ensaio de Pompa é de 8 anos, sendo que a remoção do povoado do Zabelê se deu em 1987-1988. Aquilo que cronologicamente é mensurável e contabilizado como tempo administrativo enunciado num registro numérico em uma folha de papel que lemos num golpe de vista é o tempo de resolução dos impasses legais que corre segundo um procedimento indiferente a quem está presente no conflito territorial. Do ponto de vista da experiência, estamos na seara do indistinto da suspensão, de tudo aquilo que não seja o mesmo procedimento que se manifesta pela mera sucessão de datas cuja distância pode ser simplesmente a distância entre linhas em uma folha de papel. Neste caso, o intervalo temporal é somente significado e leitura.

A espera pela conformação da regularização de um ato governamental cujo futuro e meio de concretização as populações atingidas não exercem qualquer influência direta, dada que é sempre mediada pela presença de operadores do direito, sempre corre o risco de produzir suspensões temporais as mais diversas. No triênio 2016-2018, meus primeiros anos como professor e residente em São Raimundo Nonato, foi um período em que abundaram bolhas de suspensão no território da microrregião da Serra da Capivara, assim batizada como um desdobramento da influência do Parque na região. $\mathrm{O}$ anúncio de uma agenda de mineração como parte do desenvolvimento estratégico do estado do Piauí e a presença de uma empresa mineradora no território criou uma sensação de insegurança territorial no entorno das áreas escavadas para pesquisa de prospecção que caracterizam o tempo jurídico da licença prévia. Com a chegada do inverno, ou seja, as chuvas que sofrem para cair no começo de cada ano, começou a correr a história de que os moradores das comunidades do núcleo Xique-Xique, no quilombo Lagoas, estavam com medo de semearem a terra. Vizinhos do principal poço de prospecção de minério de então, temiam perder tudo por causa exatamente daquilo que nunca souberam; aquilo que poderia ser efeito das atividades da mineradora, da possível extração de ferro em seu território. Recebi o telefonema de uma das lideranças do território, Chiquinho, em que conversamos sobre o que fazer. Decidimos que a melhor estratégia seria a de plantar, e que conviria espalhar a tática. Ainda era dezembro e a chuva forte não havia chegado. A possibilidade de perder o que se planta está inscrito na 
dinâmica da paisagem da caatinga, cujos invernos nem sempre são generosos, a despeito da infinita bondade de Deus. O risco de perder a colheita é um repertório memorial poderoso, com uma história ancestral de impacto recente. Afinal, ainda passávamos por uma estiagem que já durava 7 anos. A incerteza sobre o real teor da exploração mineral, a total falta de capacidade de comunicação da parte do governo do estado e o estabelecimento de uma agenda que se mostrava somente uma abstração a respeito do tempo futuro, mas de um tempo futuro em que eles não apareciam como personagens, levou a comunidade de Xique-Xique a pensar em abdicar da própria paisagem e, em parte, de sua vida. O receio de não poder colher a safra de 2018 por causa de uma atividade qualquer da SRN Mineração fez com que o risco de esperar tornasse algo mais grave do que a possibilidade da falta de chuvas. A incerteza flertava com a convicção de que o futuro não lhes seria favorável. E nessa história, nada de governo para mediar. Este mesmo risco, o de esperar por algo que não se sabe, e por tempo indeterminado, é exatamente o movimento flagrado pelo ensaio de Pompa a respeito do povoado do Zabelê nos idos anos 1980.

O povoado do Zabelê é pego de surpresa pela proibição vigente de qualquer atividade econômica dentro de Parques Nacionais, proibição que os atingiu tardiamente, pois durante o tempo da espera os moradores mal foram informados, ou mais, foram mal informados a respeito da existência do Parque e dos agentes de sua implementação (POMPA, 1987, p. 5) ${ }^{4}$. Mas, segundo o mesmo ensaio de Pompa, os moradores do Zabelê não eram os únicos rendidos na história. O fato de o Decreto Presidencial utilizar-se de dados cartográficos, e não geográficos, indicava que a criação do Parque e sua delimitação no papel teria se dado sem que técnicos do então IBDF (Instituto Brasileiro de Desenvolvimento Florestal) e tampouco do INTERPI (Instituto de Terras do Piauí) tivessem realizado qualquer pesquisa de campo, o que se mostrou uma característica majoritária das políticas fundiárias para o sueste do Piauí até os tempos de então. Ao mesmo tempo, a falta de cadastramento e regularização fundiária na região, dificuldade ainda evidente e determinante para todas as questões territoriais no sudeste do Piauí, impediu que se soubesse quais eram as terras devolutas do entorno do parque, produzindo um efeito de grilagem em cascata. O vazio geográfico expresso como cartografia, efeito administrativo frequente na interiorização do Estado brasileiro ${ }^{5}$, reiterado energicamente nos episódios que envolvem mineradoras na região nas últimas duas décadas, se contrapõe à necessidade de administrar a nova unidade territorial. Sendo o povoado do Zabelê o único povoado vivente dentro da área fixada naquilo que após 06 de junho de 1979 estaria decretado como sendo dentro do parque (os demais povoados seriam povoados de entorno ou da área de interesse, produzindo outra sorte de conflitos, todos resultantes do policiamento da unidade territorial), era ele quem detinha o conhecimento da paisagem, conhecimento este que deveria ser absorvido para a sua administração. Seu usufruto, no entanto, seria circunscrito exclusivamente para as finalidades do parque determinadas por Decreto Presidencial, o que altera o regime de articulação entre fins e meios que o conhecimento de então, e a partir de 1979, conhecimento tradicional - cotejado pela sua patrimonialização -, nutria. No limite, a administração desse conhecimento se dá atento à taxinomia do espaço territorializado pelos povoados como o Zabelê, mas indiferente à experiência que fazia desse mesmo conhecimento uma forma de orientação no mundo. O Zabelê, no ato da sua remoção, foi convertido em Antigo Zabelê e, portanto, em ruínas do Parque, até então desprovido de valor, inclusive arqueológico.

Este movimento, com fortes desdobramentos políticos e jurídicos, foi estudado em detalhe por Sousa (2007), referência bibliográfica importante para além de sua abordagem constitucionalista, dado que foi conduzida por uma pesquisa de campo realizada junto aos moradores do Antigo Zabelê.

5 Efeito próprio do fenômeno das fronteiras em movimento (VELHO, 1974) da colonização interna das unidades geopolíticas modernas; ou tratam os territórios como vazios cartográficos (FREIRE, 2018), ou cuidam, mediante violência, do seu esvaziamento: "Assim como a terra deve ser despojada de árvores e pedras para a agricultura, o terreno deve ser escoimado dos seus habitantes nativos. Assim como o povo de fronteira deve preparar-se para invernos rigorosos, deve também se armar contra as populações indígenas" (HARDT; NEGRI, 2001, p. 188), passagem que retrata a marcha para o Oeste nos Estados Unidos da América, mas sintetiza não poucos movimentos da história do povoamento do sudeste do Piauí. 


\section{Objetivos, objetos}

Tendo em vista que o que tomo como ponto de partida é um acontecimento cujos rastros, marcas, traumas e ruínas seguem muito presentes na conformação das questões territoriais da região de São Raimundo Nonato nas quais eu mesmo tornei-me ator, a investigação atenta cuidadosamente para relação com termos e para os termos de relação que a própria pesquisa produz. Não é tarde para dizer que as acusações, o tempo todo presentes nesse tipo de situação, não solucionariam nenhuma situação posta, especialmente porque, por diversas razões a considerar em um outro momento, aquilo que imaginamos como protótipo de solução deveria ser mediado pela intervenção legal, modo de resolução que prioriza a tutela da experiência e a solução policial-punitiva. Aqui, o objetivo primeiro é reinserir a dimensão experimental na composição das diversas territorialidades em conflito na região reconstituindo o repertório de narrativas que remontem às experiências violentas que tramam o tempo e o espaço em uma história que repete a sina da expulsão, primeiro indígena e então, as demais, dando sinais da extensão profunda da história do Piauí colonial (OLIVEIRA, 2007). É exatamente por isso que não advogo em favor de posicionamentos estanques contra tal ou qual instituição, mas sim com a intenção de investigar a expressão temporal das formas de indiferença que territorialidades distintas nutrem entre si, dando vazão a diferentes quadrantes de conjunção do passado, do presente e do futuro, propiciando ritmos de vida distintos, tensionados por uma certa temporalidade cósmica que a paisagem, a caatinga, impõe indicando assim uma estrutura temporal em que as relações são possíveis. Qualquer revisão bibliográfica a partir deste momento segue a orientação de produzir documentos a respeito da constituição das divergências territoriais na região de São Raimundo Nonato, tendo como ponto de partida o acontecimento da expulsão do povoado do Zabelê, que deve ser abordado em algumas dimensões sem nunca perder de vista que a expulsão de um povo indica não somente uma assimetria, mas a diferença de poder de instituir território e a maior parte de tudo aquilo que vem depois.

A expulsão em si é uma história longa, que ocupa uma cronologia de 9 anos. Ainda que tenha conhecimento de alguns sinais e de algumas narrativas, não há nada que permita concretizar o projeto de fazer explodir a cronologia. No entanto, de tudo o que sei e que ainda não fui autorizado a relatar, a demolição das pequenas edificações que formavam o povoado do Zabelê, sua redução a escombros, é um marco decisivo da história. A carência de justificativas e a manutenção de outros tantas casas de taipa que ocupam outras paisagens dentro do parque desafiam, inclusive, a tese de que o Zabelê era o único povoado localizado dentro do polígono do parque. Pequenos ajuntamentos, como o da Toca do Mulungú, ainda estão de pé, ainda que parcialmente, uma vez que já deteriorado pelo tempo. No caso do antigo Zabelê, a ação do tempo foi acelerada por tratores. A demolição nos sugere que tais ruínas, na medida em que orientam a memória coletiva a respeito desta história em particular, traz consigo três dimensões.

A primeira dimensão diz respeito ao design de ruínas e biografia dos objetos mobilizados para tal que, num segundo momento, deve culminar na abordagem da cultura material de quem morre ou é tornado antigo (aliança póstuma) tensionada com a cultura imaterial de quem mata ou torna obsoleto (aliança em vida). Estas três dimensões dizem respeito a pontos focais que esta pesquisa, em seu início, deve ter e que, ainda que distintas, são profundamente articuladas. Uma vez que compreendemos que as ruínas do Antigo Zabelê não compõem parte do patrimônio arqueológico do Parque Nacional da Serra da Capivara, e que a dimensão humana sob jurisdição da administração do parque toma forma segundo a lógica patrimonial, o primeiro momento deste trabalho está em compreender as ruínas como parte do patrimônio imaterial do Parque ao mesmo tempo em que, manifesta como cultura material, é patrimônio material dos antigos moradores da paisagem. Esta torção teórica, para todos os efeitos, desobediente, busca reinserir a remoção humana como condição da história presente da unidade territorial levando em consideração que a remoção não é uma casualidade, mas fruto da administração do Decreto 83.548 de 05/06/1979. E nisso entra em pauta uma determinada noção de materialidade e imaterialidade temporalizante, que encontramos na obra de Vilém Flusser (2007).

Vale notar que Flusser se indispõe com o conceito de imaterialidade, tão presente no discurso patrimonial, na medida em que este conceito aponta para uma dimensão intangível da manipulação industrial 
do estado pretérito da matéria. No entanto, esta dimensão carrega consigo questões de semântica de tempos históricos em que a análise patrimonial isola, por dever de ofício, ao negar a coetaneidade fazendo com que populações inteiras deambulem com a projeção de que são o passado de si mesmas. A indisposição de Flusser o leva a considerar o imaterial dos procedimentos, receitas, métodos, gestos e técnicas como repertório para a cultura material futura. É por esta razão que Flusser inverte a forma temporal do imaterial em que, mesmo de um ponto de vista histórico, a cultura imaterial deveria ser considerada como cultura materializadora. Neste sentido

O design, como todas as expressões culturais, mostra que a matéria não aparece (é inaparente), a não ser que seja informada, e assim, uma vez informada, começa a se manifestar (a tornar-se fenômeno). A matéria no design, como qualquer outro aspecto cultural, é o modo como as formas aparecem (FLUSSER, 2007, p. 28).

Como as formas aparecem e desaparecem,o desaparecimento é, também, um projeto. Vale anotar que abordar a totalidade da materialização do parque como produção de sua unidade territorial por meio da complexidade assombrosa do seu design é uma tarefa que garantiria seu insucesso. O que tenho em vista é a reinserção das ruínas do Antigo Zabelê, ainda que somente por meio de ficção etnográfica, como cultura imaterial do parque, ou seja, como algo que é parte de seu projeto, manifestação e, como tal, como a produção de ruínas que, até o presente momento, não se encontram inventariadas como parte de seu patrimônio e, no entanto, já não fazem parte do patrimônio, das posses, da propriedade dos habitantes do Antigo Zabelê, configurando-se até o presente momento como um espaço negativo. E é esse espaço negativo, lugar-nenhum, onde esta pesquisa busca encontrar seu terreno, cabendo então definir, na inauguração dos esforços em sua direção como imagino esse tipo de relação que compreendo ser o ato governamental que projeta a remoção, ainda que do ponto de vista governamental o projeto seja sempre outra coisa. O desafio aqui passa a ser a abordagem, isto é, como conversar a respeito de um tema tão delicado cuja administração, ou seja, a produção de documentos mostra-se tão lacunar e displicente? Como lidar com uma pletora de narrativas de uma história cuja documentação fala sempre de outra coisa? Na falta de uma alternativa efetivamente melhor, convém então falar de outra coisa; e então, de outra coisa; e seguir assim para ver se, em algum momento, será possível fazer com que o tema encontre, por fim, o material que o abrigou este tempo todo em segredo.

\section{Ética como metodologia: pesquisa e crise}

Ciente da ressonância que nutro com parte significativa dos escritos de Walter Benjamin a respeito dos conceitos de história e experiência - em particular, a ideia de que sequer os mortos estão a salvo ${ }^{6}$-, convém atentar para alguns elementos dessa ressonância. Afinal, longe de ser um acidente, nela compreende-se todo um esforço em que a metodologia tem como fundamento questões de ordem ética e política, trazendo assim implicações importantes para o que compreendo ser, da minha parte e no lugar que ocupo, o exercício da antropologia na produção de documentos originados na busca orientada por comunicação humana. Por isso atenta, antes de mais nada, para a convivência de mundos e de histórias que frequentemente colidem, deixando a imagem ecumênica sobre a diversidade cultural para um outro momento. É nesta convivência de mundos, expressa também e principalmente na precipitação da violência, que a administração da diferença assume seu lugar de direito, seu lugar no Direito - seja em programas de desenvolvimento econômico, seja na aliança entre patrimônio histórico, gestão de parques e produção de pesquisa científica. Essas atividades não são necessariamente distintas à luz da administração da diferença no que diz respeito à manutenção da unidade do território. Isto se dá especificamente na determinação governamental de territórios, pois territórios correspondem ao ato de sua fundação.

6 "Só terá o dom de atiçar no passado a centelha da esperança aquele historiador que tiver apreendido isto: nem os mortos estarão seguros se o inimigo vencer. E esse inimigo nunca deixou de vencer" (BENJANIN, 2013, p. 12). 
Se a conversão da terra em uma nova unidade, como no caso do Parque Nacional da Serra da Capivara, constitui a jurisdição de uma agência pública para fins de sua administração e consequente policiamento, ela também produz uma unidade temporal cronológica que, por diversas razões, reinaugura o tempo e, com ele, refaz o espaço a partir de novas taxinomias, novas personagens que, para fins narrativos, não se compatibilizam com as taxinomias e personagens de outro tempo. E com outro tempo eu não estou me remetendo ao que é cronologicamente anterior, mas ao que tem a sua contemporaneidade negada, desdobrando-se como um tempo outro (FABIAN, 2013). Se não estamos falando necessariamente de extermínio, estamos discutindo a remoção humana de uma paisagem pela violência de Estado, paisagem esta que teve sua história reinaugurada na unidade temporal do Parque Nacional. Esta história, ironicamente, é de fundação mais antiga do que os povoados mais antigos do entorno, hoje localizados no município de Coronel José Dias, vizinho de São Raimundo Nonato. Os monumentos arqueológicos que marcam a manutenção da presença humana ancestral, afirma Pompa (1987), estariam datados em torno de 32.000 anos $^{7}$. A unidade do Parque é narrada pela história natural da paisagem - a caatinga, a megafauna, o material lítico e as pinturas rupestres. Esta história não menciona a figura do Velho Vitorino, fundador do povoado do agora Antigo Zabelê, não permite que as populações humanas reinvistam suas moradas a partir de sua negociação com a paisagem, enfim, interrompe, corta, desapropria (POMPA, 1987; GODOI, 1993; SOUSA, 2007), da mesma forma que literatura alguma que esteja disponível chega a mencionar a figura de Marco Fava Seca, quem aparentemente inaugura a linhagem de Vitorino na região da antiga Várzea Grande, atual Coronel José Dias. A trama das relações de parentesco que se misturam com o desenho da paisagem é dissolvida, o que altera inclusive a toponímia. O Serra da Capivara, antes uma enorme coleção toponímia, é uma invenção recente então tornada antiga.

Contrária à administração progressa do tempo homogêneo do historicismo - o tempo isolado do mundo consequente, que combate o anacronismo como se fosse a manifestação do mal -, o materialismo histórico de Benjamin move-se contra a história do triunfo que faz com que cada vencedor, cada agente e figura triunfante, torne-se imediatamente herdeiro de todos aqueles que antes foram vencedores, fazendo das conquistas uma transmissão perene dos espólios de guerra e da exploração humana. Nesta tradição em que os grandes gênios estão irmanados da escravidão dos seus contemporâneos (BENJAMIN, 2013, p. 12-13), o horror da permanência do estado de exceção que se abate como realidade perene dos povos oprimidos pelos poderes de escala, que promovem a gestão do direito na forma primária da negação do tempo, é o objeto absoluto da apreciação histórica e, por conseguinte, etnográfica ${ }^{8}$ da pesquisa porvir. Isto me coloca na direção de dois imperativos éticos da pesquisa histórica e antropológica: o primeiro, o de operar por rupturas ao invés de privilegiar constantes universais e então, trilhar nas sendas dos acontecimentos como horizonte absoluto - o que nos conduz mais uma vez aos problemas da violência e do risco de sua gestão.

O acontecimento como um horizonte absoluto atrela-se aos problemas levantados, não pela razão, mas pela experiência, o que é a forma moderna de aproximar a história e as demais práticas idiográficas do risco, ao afastar a observação da panaceia apaziguadora da Razão e do Simbolismo. Estes, elementos de temática Iluminista, libertadora em sua economia interna, produzem o ambiente conceitual em que se dá a administração da diferença mediante dispositivos de controle do imaginário, tanto do administrador quanto do administrado, produzindo a tensão do trinômio bárbaros, selvagens e civilizados em que a diferença existe como a pré-história da unidade por vir, unidade que deve ser expressa segundo uma plataforma material

7 Em publicação contemporânea a de Pompa (1987), Niéde Guidon (1987/88/89) precisa a escala cronológica afirmando que "os primeiros grupos humanos devem ter chegado à região [de São Raimundo Nonato] por volta de 35.000-32.000 anos atrás, e esses grupos a colonizaram integralmente, o que implica uma adaptação ao eco-sistema da região". Esta cronologia é ampliada de forma considerável na publicação de Guidon (2009[1992]) a partir do encontro de vestígios de origem antrópica em camadas pleitoscênicas do solo. As escavações realizadas no boqueirão da Pedra Furada, iniciadas em 1978, trariam evidências de presença humana desde há cerca de 50 mil anos, data precisada por Gabriela Martin (2013, p. 61) em 48.000 anos. Temos aqui uma cronologia que crava a paisagem em uma escala temporal profunda, para muito além da escala humana. Esta escala, posta na escala BP (Before Present) opera em uma razão em que a escala do tempo humano torna-se flagrantemente insensível, especialmente diante do presente (before present).

8 O exemplo deste empreendimento em antropologia encontra-se na obra de Michael Taussig (1993, 1994, 2004). Não surpreendente, o mesmo modo de atenção à história, no caso, do sudeste do Piauí encontra-se no livro da liderança quilombola Antonio Bispo dos Santos (2015). Esta correlação, ou confluência, de esforços a um modo de atenção histórica é parte do trabalho que este projeto pretende discutir. 
em que a informação esteja disponível e codificada. Nela, a tradição antropológica tem lugar certo e é nesta prática de pesquisa, disciplinar, que enveredo daqui por diante.

Os artigos intelectuais sobre cultura material, especialmente os produzidos antes da semiótica de Alfred Gell e a temática da agência dos objetos, mostram aquilo que talvez seja o maior e mais cuidadoso refino da prosa etnográfica, onde um horizonte metodológico toma forma e apresenta um programa de pesquisa protocolar. Independente da matriz teórica, as práticas descritivas e a coleta de objetos no cotejo com a paisagem que, lidas com apuro arqueológico, instituem ruínas como as pegadas por onde pisar, dão a segurança a partir da qual a antropologia expande suas fronteiras de mãos dadas com a modernidade. Nisso, a sutileza da discussão da arte cerâmica de Franz Boas, os motivos gráficos arapash abordados por Alfred Kroeber, a ergonômica comparada de André Leroi-Gourhan, a precisão de manual da recomposição de técnicas de cestarias produzidas por Berta Ribeiro, todos apontam para técnicas, gráfismos e práticas de linguagem que constituem o paradigma das práticas de patrimonialização. Critérios objetivos, como os elementos de ergonomia, a primazia da percepção corporal e da atividade humana, problemas de materialidade tomam forma como os a priori da imaginação simbólica na medida em que operam como o elemento comparativo por excelência. E aqui, o comparativismo é de outra ordem, uma vez que o que está em questão não é o sentido, cujo fundamento das pesquisas linguísticas foi duramente criticada por Berta Ribeiro, mas o das soluções técnicas que negligenciam por completo o problema do contexto. É a escala planetária do terreno em que a noção de difusão opera em primeiro lugar, cabendo então destacar não somente as zonas e o fundamento do intercâmbio técnico, mas as razões pelas quais povos isolados encontraram soluções técnicas similares a despeito da profunda diferença que poderíamos definir como sendo da ordem da cultura.

Abordar este arco histórico com vistas na fundamentação de uma semântica dos tempos históricos que discuta os modos de concretização da administração da diferença com relação aos quais a pesquisa antropológica, independente de sua matriz teórico-metodológica, tornou-se especialista nos joga no centro de um debate político da maior importância, o debate sobre as duas modernidades. Este debate nos obriga a atentar para o binômio sentido//presença nos afazeres de pesquisa que, uma vez correlacionados, expõe a ambiguidade da expansão moderna das instituições europeias e a constituição de uma ordem econômica global propiciada pelas instituições que, a depender do ponto de vista, faz algo indistintas, tanto as instituições coloniais quanto as de caráter republicano (HARDT; NEGRI, 2001). A expansão em questão, aquela que acaba definindo o lugar da pesquisa etnográfica, e não só ela, mas também do direito comparado, da religião comparada e de outras formas de arqueologia do século XIX, acaba por determinar novas unidades analíticas que fazem da pesquisa científica um compromisso com toda uma infraestrutura de circulação de coisas, pessoas e animais. Missionários e marinheiros tornam-se informantes de diversos cientistas, desde Robert Boyle e conde de Buffon até Edward Burnett Tylor e Marcel Mauss. As coleções registram todo tipo de curiosidades que, com o advento da anatomia comparada, deixam de ser organizadas exclusivamente segundo o patrimônio do colecionador, de forma a serem compostas segundo a pesquisa sistemática de sinais diacríticos dos tipos normais, expressa por médias e medianas estatísticas, e das monstruosidades como sua antítese. Zoológicos, por fim, fazem da comparação uma forma presente e doméstica da amplitude do empreendimento somente possível a partir de um enorme repertório técnico em que elefantes podem compartilhar com a presença humana o espaço de navios a vapor, sendo então transportados para os jardins em que seu confinamento perpétuo com a finalidade de sua exposição e, para algumas formas retóricas, sua conservação. As viagens são realmente uma aventura, e a tecnologia comparada mostra-se fruto da possibilidade das tecnologias que sustentam a comparação em escala global no plano econômico e estratégico. A prosa etnográfica a respeito das tecnologias humanas é, assim, um exemplo formidável do advento do Iluminismo, oferecendo um conhecimento propriamente enciclopédico a respeito da concretização das relações humanas com seu meio circundante. No entanto, ela traz consigo uma carga que se torna muito pesada quando abordada antes eticamente do que pelo rendimento intelectual.

A possibilidade técnica da viagem, não somente a humana mas também a do elefante, respeita e depende de duas formas de produção de espaço homogêneo. A primeira atende para o empenho técnico-científico para ocupar e circular nesse mesmo espaço homogêneo em que a metrificação deve tecer suas alianças com 
a termodinâmica da revolução industrial, que produz uma nova balística, de assalto, e grandes contingentes de deslocamento por veículos automotores portando cargas pesadas. Este empreendimento faz do espaço planetário um enredamento global sucessivo que respeita, antes de mais, a elaboração da unidade espacial como algo tecnicamente viável, isto é, sujeita à administração racional, encadeando da forma mais econômica os meios e fins, o que seguramente envolve o trabalho escravo e precário com a finalidade de produção de mais-valia. No entanto, para fins de sua concretização humana, a viabilidade política é igualmente pertinente de forma que a expansão bélica e a supremacia armada imperial possam garantir o fluxo de pesquisas para todos os fins, desde que não violem o pressuposto do nomos e da soberania, o que seria sedição ou, mais adiante, violência revolucionária. $\mathrm{O}$ desdobramento de uma ordem jurídica imperialista, como a acima descrita, fundada em um design supranacional do poder político, que Hardt e Negri (2001) chamam de Império (i. e. abolição das fronteiras) tornam ainda mais grave a instituição da unidade planetária que serve de garantia para todas as formas de generalização propiciada pela diversidade de fluxos circulantes em uma mesma estrutura logística conectiva.

Desta unidade em que o Império funda uma ordem espacial compreendemos como a presença humana em escala global pode ser praticada para além, e muito além, dos fluxos populacionais que demarcam a distribuição e sua espécie em contextos como o do pleitosceno dos sítios arqueológicos. Essa presença é fruto de uma nova ordem global inaugurada pela modernidade em que a viagem torna-se um quesito obrigatório da pesquisa empírica e que a comparação constitui-se paulatinamente como fundamento das práticas de administração pública, porque coloniais. Estas questões, todas antropológicas, nos obrigam a enfrentar um outro problema, especialmente à luz do processo agressivo e totalizante de instituição da história natural/universal como eixo das relações econômicas reais do capitalismo imperial. A universalização do espaço posto como passivo de sujeição às técnicas de medição e consumo de energia humanos tem uma contraparte fundamental, o da universalização do Tempo. E aqui me aproximo decisivamente das pesquisas de Johannes Fabian:

Diferentes graus de universalização do Tempo foram, naturalmente, alcançados de um modo abstrato pelo pensamento filosófico anterior. De fato, o "Tempo universal" provavelmente se estabeleceu concreta e politicamente na Renascença, em resposta tanto à filosofia clássica como aos desafios cognitivos apresentados pela era das descobertas que se abriu na esteira da circunavegação da Terra. No entanto, há boas razões para buscar progressos decisivos, não nos momentos de ruptura intelectual alcançados por Copérnico e Galileu e nem, aliás, por Newton e Locke, mas no século que elaborou mecanismos de discurso que agora reconhecemos como os fundamentos da antropologia moderna - a era iluminista (FABIAN, 2013, p. 41).

A determinação de um tempo universal e, portanto, sincrônico e global não poderia operar simplesmente pelo golpe intelectual de gênio. Aliás, faria pouco sentido se não tivesse se tornado corrente em escala compatível com suas exigências, o que muito dificilmente se torna real pela força das ideias, estas siblings de seus escravos (BENJAMIN, 2013, p. 13). A difusão da possibilidade prática de um Tempo global se dá na medida em que este mesmo Tempo pode ser administrado, da mesma forma em que o espaço global é universal na medida em que passa a ser recomposto como correspondente a uma infraestrutura que faculte acesso a toda a sua extensão e a totalidade de suas riquezas - o que se transformou em valor econômico, demarcando a autonomia relativa da administração financeira. Este exercício, antes de existirem os meios técnicos de sincronização global deste novo tempo, tem como primeiro fundamento a técnica de discurso de produção das etapas do tempo universal que conferem ao tempo sua qualidade sintética. Fabian encontra em Bossuet aquele que, em seu Discours sur l'histoire universelle, elabora a estratégia da abreviação das unidades temporais que permitiriam ao leitor apreender os movimentos em um só lance (FABIAN, 2013, p. 42). A história universal inaugura um exercício editorial em que o gesto de virar as páginas equivale a um tipo de show of hands da prestidigitação. O essencial do mundo disponível em uma tecnologia de leitura e no exercício do golpe de vista - coup d'oeil. É este golpe que, no entanto, torna visível aquilo que, de outra maneira, exigiria uma história com o comprimento da história universal. 
Esse primeiro momento inaugura o arquivo temporal dos tempos, arquivo onde as épocas se organizam na mera sucessão temporal, fazendo da cronologia um exercício também qualitativo. A Sicenza Nuova de Giambattista Vico, ou mesmo a Essai sur le moeurs de Voltaire são produtos interessantes desta estratégia em que o tempo é reunido em unidades presididas por uma ordem não somente transcendente, mas soberana. A sucessão confere ao tempo sua qualidade e permite que a comunicação entre o escritor e o leitor esteja sujeita à apreciação adequada e à possibilidade de determinar a melhor qualidade de um determinado evento, o que sujeita o ordenamento à possibilidade da crítica que responde, em tese, o anúncio de Immanuel Kant sobre o que seria o Esclarecimento. O tempo secularizado responde a premissas muito claras da comunicação moderna. No entanto, o que carece de clareza quanto aos seus fundamentos é exatamente este tempo secularizado que tinha como problema um elemento em comum com o desafio posto pelo espaço infinito da astronomia (KOYRÉ, 1979): o tempo profundo (GOULD, 1991; ROSSI, 1992). O desafio, de um e outro, é fundamentalmente quantitativo e, portanto, o de preenchimento. E, convém lembrar, a quantidade é uma qualidade para o eixo cartesiano de espaço-tempo:

\begin{abstract}
A verdadeira razão pela qual a cronologia bíblica teve de ser abandonada era o fato de não conter o tipo certo de Tempo. Sendo calculada como o Tempo após a criação, conforme fora revelado pelas Escrituras, ela era o Tempo da salvação de Bossuet. Era o Tempo da transmissão de eventos significativos, míticos e históricos e, como tal, era crônica, bem como cronologia. Como uma sequência de eventos mostrava-se linear, em vez de tabular, ou seja, não permitia ao Tempo ser uma variável independente dos eventos que assinala. Por isso, não poderia fazer parte do sistema cartesiano de coordenadas de tempo-espaço que permitisse ao cientista traçar uma infinidade de dados rotineiros sobre o tempo neutro, a menos que ele fosse primeiramente naturalizado, isto é, separado dos acontecimentos significativos para a humanidade (FABIAN, 2013, p. 50).
\end{abstract}

O tempo passa a ser um elemento tomado como pressuposto. Relevante somente em escalas ou profundas ou infinitas, ele passa a se destacar paulatinamente do ordenamento como uma questão posta que, ao contrário do espaço, é discutida em uma profusão de pesquisas a respeito da ocupação das populações humanas no globo, deixando de ser um objeto para ser uma pré-condição da comunicabilidade do argumento. O tempo torna-se, nas mãos do evolucionismo em antropologia, e além, do evolucionismo antropológico, uma questão de espaço e, mais particularmente, de distância (FABIAN, 2013, p. 52).

Entendendo que as condições epistemológicas do conhecimento moderno exigem do pesquisador uma fórmula, ainda quando meramente retórica, de distanciamento do objeto, o tempo enclausurado nesta mesma fórmula torna-se uma moeda política na medida em que a instância da coetaneidade é negada. Tempo propriamente espacializado, o afastamento que é espacial força ao tempo a produção de uma correlação entre saber e o pretérito perfeito, ou seja, o passado absoluto de uma cronologia fixada e protocolar. E sabemos bem o valor que os protocolos de pesquisa têm para as ciências da natureza. Independente da primazia que o dado empírico ou a pesquisa de campo têm na confecção de uma determinada pesquisa de dimensões antropológicas, esta mesma dimensão impõe o afastamento que, até o presente momento, é garantido pela noção de um tempo evolutivo, isto é, universal, homogêneo. A aparência de que a cronologia do tempo profundo organiza automaticamente todas as experiências talvez tenha seu fundamento em uma espécie de conforto visual de uma paisagem povoada por distâncias tão generosas que não oferecem nada à primeira vista, sugerindo ser um território vazio e de ocupação promissora, Terra Prometida. Se a tarefa da antropologia culmina em um tempo que não seja o presente do produtor do discurso antropológico, ou seja, administrativo, se as relações travadas que, por fim, possibilitaram os meios de tornarem a pesquisa de campo uma forma presente de relação, são relegadas a um passado utilitário desse mesmo tempo a ser localizado na mesma cronologia, então as relações dadas no Tempo, a própria comunicação humana compreendida enquanto dimensão da relação é esquartejada. A diversidade da forma presente é negada na mesma medida em que a constituição de uma forma autoral auto-evidente toma lugar constituindo o espaço autoral da autoridade de pesquisa. A negação da coetaneidade aparece aqui como a cumplicidade cognitiva com as práticas de colonização do 
tempo-espaço, frequentemente denunciadas em suas formas políticas e morais. E, neste caso, levando em conta a persistência da pesquisa de campo em antropologia como forma de administração do dado - empírico, contábil - e, portanto, administração da diferença, a cognição é necessariamente política.

Esta última afirmação deixa de ser polêmica na medida em que cada pesquisador reconstitua os passos da pletora de soluções práticas para a viabilização de suas pesquisas de campo, as situações em que teve que desempenhar todo tipo de papel para que pudesse simplesmente estar-lá, isto é, viajar nas condições minimamente favoráveis, o que inclui, obviamente, as de segurança e o quanto esta prática está amparada por uma ou outra forma de direito e em uma profissão ou atividade econômica. É neste sentido, para além de todos os outros imprevistos que a pesquisa de campo impõe ao pesquisador, que a natureza da reflexão etnográfica, a ser fundada antes em uma ética do que em um programa epistemológico, permite que se abandone a fé na distância (FABIAN, 1990:755), colocando as formas e práticas da representação da diferença humana sob suspeição. Seguindo na esteira estendida por Fabian, convém notar que ele não abre mão de certa noção de representação. Ele entende em quê a crítica etnográfica da etnografia, frequentemente orientada pela mera transcrição da voz dos sujeitos de pesquisa, não representa a voz alheia somente por transcrever um documento de áudio, ao invés de interpretá-lo à luz de uma ou outra metodologia. Ainda assim, e talvez exatamente por isso, a representação como instância segue oferecendo não poucas dificuldades com as quais uma pesquisa que se paute antes por uma relação ética de comunicação do que por um paradigma epistemológico. A questão não pode, e não deve ser a designação do melhor representante, mas fundamentalmente a orientação ética de que a etnografia torna-se o registro de uma ausência com a qual o pesquisador está, antes de mais nada, comprometido. Nas palavras do próprio Fabian:

we anthropologists should perhaps not think of representation in the first place as some enabling capacity of the human mind (although investigations of such capacity remain legitimate for psychologists, brain, scientists, and philosophers), but more modestly, as something that we actually do, as our praxis. This would help us to realize that our ways of making the Other are ways of making ourselves. The need to go there (to exotic places, be they far away or around the corner) is really our desire to be here (to find or defend our position in the world). The urge to write ethnography is about making the then into a now. In this move from then to now the making of knowledge out of experience occurs. Both movements, from here to there and from then to now, converge in what I called presence. This is the way I would define the process of othering (FABIAN, 1990, p. 56).

A premissa ética é tão pertinente quanto é complexa. É com ela que me comprometo. No limite, o que Fabian sugere é que o exercício da representação como dimensão da pesquisa científica oferece o mesmo sinal de crise que as diversas instâncias eleitorais gozam quando a maior parte população não está simplesmente sujeita ao trabalho degradante e a formas subalternas de imaginação política. O pressuposto de uma representação mais ou menos adequada produzida em grandes centros, de uma forma geral, emula sistemas de sufrágio em que o patriarca vota pela família e pela propriedade - tanto metafórica quanto literalmente. A representação corresponde assim a um conjunto pequeno de variáveis e seus ajustes seguem operando em favor da manutenção de um centro estável que advoga em favor de uma imagem perene de si mesmo e da ordem que defende. O que aparece na etnografia como conduta ética diante da diferença - o que não é necessariamente uma regra - é que ela emerge como uma prosa sobre o tempo e a presença com relação aos demais em que os mecanismos de representação podem se tornar menos absolutos, menos afeitos a políticas totalizantes e totalitárias, e suas formas mais acessíveis ao cotejo e confrontação, mais afeitos à vida presente. A etnografia, ou no caso, a pesquisa pode operar, assim, pela deflação da mídia pela qual representa o outro. Mas como? 


\section{Sobre os usos opressivos do tempo e as histórias que tendem a zero}

Sabendo que minha pesquisa, ainda em gestação, opera num quadrante amplo e múltiplo a respeito dos contextos de expressão da memória, da composição dos tempos e toda a tecnologia política de sua negação; e que o ponto de partida se dá em sua manifestação expressa materialmente, seja na forma de ruínas ou de documentos; na forma de conversas travadas entre pontos de vista sempre assimétricos; a expressão do tempo opressor que constitui a forma majoritária da vitória política e territorial e do triunfo manifesto documentalmente pela supressão do tempo de coletivos inteiros, derrotados ou conquistados, oferece uma dificuldade para qualquer orientação metodológica que não seja, antes, uma tomada de posição. É assim que a metodologia tomada como ética deve preservar a ideia de que não somente a memória é um acontecimento que se manifesta em uma pletora de dimensões indeterminadas a priori, como os conceitos utilizados para mobilizar o repertório memorial compartilham dessa complexidade sem com isso operar de forma sincrônica e espelhada. Isso implica na rejeição de quadrantes privilegiados da memória reincorporando assim todos aqueles excluídos do ordenamento oficial e razoáveis, exatamente os que se mostram alucinantes, irreais, inventivos.

Se por um lado a dimensão material manifesta na constituição das ruínas mostra-se como um desdobramento obrigatório de uma pesquisa que atenta para a história própria do cruzamento do repertório de experiência e pobreza, a barbárie manifesta como o negativo dos documentos de cultura (BENJAMIN, 2013 , p. 85-90) demanda uma atenção específica, especialmente na medida em que não pretendo repetir aqui a algazarra que certo argumento militante produz, o de confundir conceito com política. Não porque conceitos não expressem questões políticas, mas porque a vida dos conceitos não coincide necessariamente com o espectro das intenções e estratégias políticas de um contexto de comunicação em particular. Mas uma vez que a discussão que captura minha atenção e presença, no presente momento, é a expressão espacial da opressão temporal/supressão temporal, é preciso discutir a conformação documental de acontecimentos como o Parque Nacional da Serra da Capivara e a política constituída como Agenda Territorial para além de um sistema de acusações que divide o universo a ser considerado em posições antagônicas estanques. É a compreensão da complexidade histórica, especialmente porque orientado por pressupostos éticos que articulo na primeira pessoa, ora no singular, ora no plural. Isto porque a simplificação da compreensão de processos históricos sempre tende à adesão do argumento vencedor expresso na forma de arquivo, produzindo uma seara de eventos conspiratórios e ajuizando em favor de um poder acumulado que é frequentemente tão inverossímil quanto perigoso quando expresso na forma de capital. Neste sentido, o aporte da história dos conceitos segundo a orientação de Reinhart Koselleck $(2006,2014)$, que dialoga com as intuições de Walter Benjamin, permite que enfrentemos uma das dimensões da expressão documental da história que nos coloca exatamente nos entrecruzamentos das diversas dimensões que os mesmos documentos registram. Esta dimensão é a semântica dos tempos históricos, que é antes uma encruzilhada, um ponto de passagem. É a infra-estrutura da mensagem.

Antes de qualquer coisa, seria preciso atentar para o fato de que a história de conceitos que se ocupa da semântica dos tempos históricos, tal como sugerida por Reinhart Koselleck $(2006,2014)$, está comprometida eticamente com elementos que se mostram indispensáveis. No caso, a recuperação nos documentos abordados da expressão de antinomias que, ao exprimirem antinomias políticas expressas na forma de antinomias assimétricas, permitiriam que recuperássemos algumas dimensões experimentais de um passado histórico. Ainda que estivéssemos restritos a uma dimensão retrospectiva da história, a história dos conceitos aponta para o acontecimento histórico mais do que para a sua organização, reconstituindo sua intensidade. E com intensidade, vale ressaltar, quero dizer violência.

Mas o que é um conceito? Como ele opera na chave de uma história em que a experiência histórica é tematizada na sua expressão temporal? E o que tudo isso tem a ver com a violência? Koselleck apresenta uma versão mitigada do compromisso ético de Walter Benjamin, a saber, a respeito do sexto aforisma de Sobre o conceito de história (2013, p. 9-20). É a partir de Epiteto, escreve Koselleck, que o conhecimento histórico toma forma na frase que diz que "não são os fatos que abalam os homens, mas sim o que se escreve sobre eles" (KOSELLECK, 2006, p. 97). Entendendo que a forma material predominante da memória oficial 
e burocrática, o registro de sua precisão, respeita o acordo midiático da inscrição alfabética e, sempre que possível, impressa, o horizonte do registro escrito como fundamento da compreensão histórica posiciona o investigador como leitor. E o leitor não tem acesso ao tempo, mas sim à sua matéria a qual ele decide ler ou organizar. O leitor se move na paisagem dos movimentos capturados num só lance para os quais Fabian chama a atenção.

O conhecimento filológico é arguto e exaustivo em afirmar que a ordem documental exprime, antes de mais nada, a língua na qual o documento fora redigido. Nisso, são a compreensão e a precisão do vínculo linguístico entre significante e significado, assim como uma orientação taxinômica dos elementos de morfologia e sintaxe, os pressupostos fundamentais para a prática da tradução que lhe é própria. Isto faz com que seja possível reinserir o documento na língua, na sua matriz histórica, e o kosmos que o orienta. Este horizonte, de fundamento majoritário, não atenta necessariamente para dimensões experimentais. A função de significação que presta serviços à taxinomia dos tempos, isto é, à sua representação, tem mais atenção ao regime estratigráfico da cronologia do que em dialogar com a experiência que não tem lugar na ordem administrativa do arquivo que dá unidade à história organizada em taxinomia.

Obviamente que o horizonte do empreendimento não é e nem poderia ser o acesso às experiências vividas no passado. O repertório técnico para tal encontra-se em outro cabedal em que as práticas de terreiro das religiões africanas e as variações xamânicas e benzimento teriam muito mais a ensinar do que poderíamos antever. Para tal seria necessário aprender, como em outro momento nos disse Evans-Pritchard, a dançar a questão (1978, cap. 5). Entendendo a variedade singular que a noção de experiência introduz ao problema da história, o que temos em mente é compreendermos que o recuo historiográfico tem o compromisso ético de resguardar às diferentes formas de experiência histórica o seu lugar e suas posições irredutíveis às grandes unidades que estabelecem a administração do espaço como configuração de um tempo histórico decalcado. Essas unidades são formadas pela conversão da paisagem no território cujo idioma político é constituído conceitualmente, de forma projetiva (KOSELLECK, 2006, p. 98-104; FABIAN, 1986) mediante severa batalha semântica que Antonio Bispo dos Santos, meu vizinho de São João do Piauí, em sua agenda contra-colonial escrita no epicentro da luta quilombola no estado, chama de "guerra de denominações" (2015, p. 47-55). A distinção entre guerra e batalha é mais do que semântica, como a própria semântica saberia apontar. É um problema a ser colocado nos termos da experiência, na medida em que a guerra não antecede o fim, da mesma forma em que nada garante que o fim não opere como começo.

A batalha semântica vista segundo a simetria do gestos constitutivos no presente do passado encena a mobilização da linguagem na inscrição do tempo histórico segundo a forma constituinte, e não constituída. Daí o valor tático de uma abordagem semântica ao invés da abordagem estrutural. Ela recupera a mobilização dos recursos experimentais da linguagem como forma de colocar em perspectiva os acontecimentos compreendidos enquanto linguagem, colocando em tensão a longa duração com a singularidade das surpresas que indicam que de fato experimenta-se algo (KOSELLECK, 2014, p. 33, 61). E ainda que o recurso estatístico da longa duração permita que leiamos elementos da repetição experimental reunidos em unidades geracionais, um determinado compromisso ético se coloca como prioritário exatamente porque nele encontramos o fundamento da pesquisa histórica/etnográfica do acontecimento como, ela mesma, acontecimento.

Em termos propriamente analíticos o problema se configura da seguinte forma. Ao contrário das premissas exclusivamente progressivas, o tempo em que as experiências singulares estão em constante tensão com o repertório memorial da repetição apresenta estratos em modos temporais (novidade, rearranjo e fundamentação hermenêutica) que precedem as aquisições concretas de experiência. E a aquisição concreta da experiência é, por sua vez, a atribuição de sentido singular e coletivo. Esse movimento em que diversas formas temporais mobilizam estratos diferentes em formas complexas de contemporaneidade - como a de ajuizar que "bom era antes" no mesmo enunciado que diz que "antes não tinha nada" e "agora temos tudo" da concepção temporal da história do território hoje chamado Serra da Capivara (FREIRE, 2018) - nos obriga, eticamente, a recuperar a tensão entre a história dos vencedores e sua expressão, propriamente experimental, nos conceitos antitéticos assimétricos. 
Metodologicamente Koselleck me coloca em um embaraço ético exatamente no momento em que sua contribuição mais se aproxima da orientação que adoto. Isto porque a tão propalada história dos vencedores, frequentemente alvo de discussões de ordem crítica, desdobra-se em um fatalismo que somente em uma ordem documental abundante faria sentido. A dialética entre a surpresa e o rearranjo das categorias de experiência aparece como um motor antropológico que, na figura da história dos conceitos, faz emergir como fatalidade a falência da história dos vencedores de qualquer concurso, seja ele bélico ou ideológico. Esse que, nos diz Koselleck, é um "axioma da experiência que sempre se confirmou", ou seja, que as condições características do longo prazo sempre escapam ao controle do argumento vencedor. Os pontos cegos e tudo aquilo que a historiografia não conseguiria preencher como evento estaria, por fim, na versão dos derrotados. A derrocada do triunfalismo oficioso, seja ele estatal ou de qualquer outra ordem, são favas contadas. No máximo, em longo prazo. Tendo em vista a realidade de populações que se movem no espectro geográfico da experiência colonial das Américas, este é um tempo que pode não estar tão sujeito à revisão historiográfica, determinando a força da unidade de arquivo que determina a falência da consciência histórica de quem vence as batalhas.

A derrota é o que, documentalmente, toma a forma de uma batalha semântica fundamental. É uma experiência que não se aprende e tampouco se transmite fazendo da experiência adquirida um complexo temporal durável. São colocados em questão todos os pressupostos metodológicos, as justificativas e prognósticos gerados por um ponto de vista que apregoava segurança e previsibilidade cósmicas. O sistema de crise próprio do pensamento moderno, que faz da crítica uma atividade de coordenação dos desencaixes coletivos mais agudos, transformou esse movimento em tema. Nesse contexto temporal, o movimento expressivo apresenta uma outra forma de derrota.

O grande tema da história passou a ser não só a mutabilidade de todas as coisas, os mutatio rerum, mas a própria mudança. Desde então, temos um novo tipo de vencidos: os que se veem ultrapassados pela história ou pelo progresso, ou que assumiram a tarefa de alcançar ou ultrapassar esse processo. Desde então, a visão da história não é influenciada apenas entre política e geografia, como, de uma forma ou de outra, já foi o caso. A posição social e econômica é que decide quem fica para trás e quem avança. É a história "burguesa" no horizonte da experiência primária do progresso e de suas consequências (KOSELLECK, 2006, p. 68).

As disputas que produzem as clivagens determinantes para que alguém possa ter a experiência da derrota tornam-se inscrições, se tanto, de um diagnóstico da falta de poder e que, exatamente pela falta de poder, torna-se um componente potente de percepção das condições de vida pautado pelos limites da ação e pelo esforço contra-celebratório que uma investigação como esta exprime. Mesmo que Koselleck tenha a paciência de um historiador, elemento dificilmente aceitável em contextos de contenda política real, o que depreendemos é uma adesão tão ética quanto epistemológica a respeito do fundamento da atividade historiográfica: o compromisso contra-majoritário. Esse compromisso revela, por sua vez, uma condição tão tensa quanto a descrita por Benjamin no sexto aforisma Sobre o conceito de história (2013, p. 12): "Só terá o dom de atiçar no passado a centelha da esperança aquele historiador que tiver apreendido isto: nem os mortos estarão seguros se o inimigo vencer. E esse inimigo nunca deixou de vencer." Entendendo que os espólios da vitória são recolhidos por um vencedor que não está predeterminado substantivamente, a investigação semântica dos tempos históricos recupera a expressão da experiência dos atos de disputa e na constituição das assimetrias de poder e, portanto, de classificação e identidade.

Nesse sentido, aquilo que Koselleck toma como evolução histórica dos conceitos antitéticos de fundamentação histórica, aqui só pode ser apreendido como mito de origem das instituições, as mesmas que oferecem uma ordem documental disponível fracamente, quase que exclusivamente detida no exercício da história oficial, ou seja, do Estado. Obviamente que a propriedade mitológica não pode estar restrita à dimensão da ausência da história, como a imaginação historiográfica insiste em dizer. A mitologia está atrelada a uma dimensão fundante do acontecimento, a de servir de ambiente, narrativo, onde as distinções cósmicas 
fundamentais são narradas e presentificadas segundo suas potências, diferença e surpresa sendo, portanto, experimental. No caso, a perspectiva posta no eixo da longa duração onde seu fatalismo metodológico toma lugar nos permite negociar com maior cuidado exatamente a expressão temporal do tempo evolutivo que constitui em grande parte a expressão jurídico-temporal da jurisdição de territórios. E é na expressão temporal que, quando articuladas com os conceitos antitéticos assimétricos, encontramos o reduto tão delicado do colonialismo e o policiamento das histórias que tendem a zero.

Tomando o cuidado de "evitar o erro de confundir história política com linguagem conceitual", Koselleck discute a expressão temporal da semântica histórico-política. Nisso, as antíteses assimétricas devem permitir que a leitura historiográfica reconstitua os estratos temporais da experiência humana a partir de pares de oposição assimétricos que são característicos de disputas políticas que determinam distinções de tipo vencedores e derrotados. Nisso:

Os conceitos antitéticos são especialmente apropriados para conformar as múltiplas rela-
ções, de fato e de intenções, entre os diversos grupos, de modo que os afetados por eles em
parte são violentados, e em parte - na mesma proporção - adquirem capacidade de ação
política. O reconhecimento desse dinamismo exige que se questione o uso dos termos no
passado. Por isso, aqui se faz distinção entre os termos dos conceitos antitéticos que histo-
ricamente pertencem ao passado e as estruturas semânticas neles empregadas e contidas
(KOSELLECK, 2006, p. 195).

A estrutura semântica, isto é, a fundamentação do sentido na sua expressão linguística, não depende de um vocábulo específico, mas de uma assimetria cuja estrutura se repete, dando profundidade temporal a uma determinada forma de opressão histórica. Nesse caso a sequência cronológica é irreversível - apontando, convém destacar, para uma dinâmica. Os três pares que Koselleck aborda como forma de se aproximar do problema revelam uma dimensão da modernidade que é bastante delicada, em que um determinado uso opressivo do tempo pode ser considerado como tempo suprimido. No caso, as antíteses entre helenos e bárbaros, cristãos e pagãos e humanos e não humanos oferecem estruturas temporais distintas fundamentais.

No primeiro caso, ainda que o barbarismo exprima uma impossibilidade do estrangeiro falar a língua vernácula, ela indica o reconhecimento de sua posição com o exterior e, portanto, fundamentalmente territorial. No segundo caso, a insinuação grega transforma-se no tema da dignidade e, paulatinamente, na demanda por tolerância na medida em que a relação de oposição oferece uma tensão temporal, podendo chegar à negação da parte contrária, expressa nas Epístolas de Paulo de Tarso, por exemplo. O espaço da experiência é deslocado para o horizonte de expectativas tendo como horizonte a negação do outro, que é ou ausência pagã, ou a negação de si da heresia. O terceiro caso, cujo impacto na antropologia contemporânea é total, é um sistema de convivência das antíteses com uma tese derradeira, a da referência à humanidade universal que não permite a exclusão humana de nenhum ser humano.

Se, apesar disso, surgem conceitos antitéticos visando a aniquilação do outro, é preciso reconhecer neles uma possibilidade ideológica que, por definição, os conceitos anteriores não podiam conter. Aparentemente, a distinção entre o dentro e o fora, inerente aos dois primeiros pares de conceitos, deixa de existir no horizonte de uma humanidade única. Se, apesar de tudo, ela se infiltra, surgem consequências que todos têm que enfrentar (KOSELLECK, 2006, p. 197).

O risco está na emergência de conceitos antitéticos assimétricos em uma estrutura temporal em que o que está posto é a possibilidade de humanidade negada - como prevê a discussão sobre a biopolítica (AGAMBEN, 2007; ESPOSITO, 2017). E a emergência desses conceitos pode muito bem ser a repetição de vocábulos como bárbaro, selvagem ou pagão que articulem então outra forma de assimetria fundamental. Se a estrutura temporal e a estrutura semântica que exprimem forem outras, então estamos lidando com uma realidade 
distinta. A distinção de tais realidades se exprime das formas mais peculiares que frequentemente desafiam a lógica até o ponto em que percebemos serem mecanismos econômicos que comunicam uma determinada realidade com apuro e objetividade. A distinção entre bárbaros e selvagens, por exemplo, está na base do etnocentrismo helênico que ordena a possibilidade territorial da escravidão e que permite que dentro do território, o senhor e o escravo sejam amigos e, fora, inimigos, produzindo assim uma experiência política peculiar, orientada em estratos postos em conceitos como zoé e biós. A assimetria está na determinação do fora como alguém a ser assujeitado pelo governo de quem está dentro (KOSELLECK, 2006, p. 200). A noção de grego anteposto ao de bárbaro por usufruto da língua nos leva para um outro campo, não determinado pelo território, mas pelo acesso a determinados meios de comunicação que apontam para uma complementaridade dos polos e não para a simples negação do oposto.

Onde quer que existissem unidades de ação política capazes de projetar de dentro para fora, ou além-fronteiras de fora para dentro, a figura de linguagem assimétrica continuou viva, e com ela o conceito de bárbaro, que sempre podia ser aplicado com novos conteúdos, inclusive de forma positiva (KOSELLECK, 2006, p. 203).

O passo dado pelo monoteísmo cristão nessa suma histórica opera na dimensão exclusiva da fé no anúncio da antítese, negativando a descrença de todos aqueles cuja atividade é outra que não a monopolein eclesiástica. Nisso, o evangelho de Paulo figura ainda como documento maior de formalização deste compromisso que constitui os estratos da distinção entre cristãos e pagãos, confrontando "coisas não comparáveis para, por meio da negação do mundo sensível, tornar real o que parecia inacreditável" (KOSELLECK, 2006, p. 207). Paulo nega a existência da singularidade dos povos apontando a universalidade da salvação e, portanto, a universalidade da missão com vista na fuga da condenação eterna. É aí que aparece a temporalização daquilo que se afirmava somente como território: o convertido como homem novo. A "totalidade - anterior - de todos os homens pode, por negação, ser confrontada com a - potencial - universalidade dos cristãos" (KOSELLECK, 2006, p. 208) - tal como escrito nas Epístolas de Paulo, em particular em II Coríntios 14-19.

Pois a caridade de Cristo nos compele, quando consideramos que um só morreu por todos e que, por conseguinte, todos morreram. Ora, ele morreu por todos a fim de que aqueles que vivem não vivam mais para si, mas para aquele que morreu e ressuscitou por eles. Por isso, doravante a ninguém conhecemos segundo a carne. Também se conhecemos Cristo segundo a carne, agora já não o conhecemos assim. Se alguém está em Cristo, é nova criatura. Passaram-se as cosias antigas; eis que se fez realidade nova. Tudo isto vem de Deus, que nos reconciliou consigo por Cristo e nos confiou o ministério da reconciliação. Pois era Deus que em Cristo reconciliava o mundo consigo, não imputando aos homens suas faltas e pondo em nós a palavra da reconciliação (BÍBLIA DE JERUSALÉM, 2002).

A temática do Novo Homem convertido foi extensamente discutida nos termos de uma teologia política, com resultados tão diversos quanto o são os trabalhos de Jacob Taubés, Giorgio Agamben e Alain Badiou - neste caso, um elogio a Paulo a partir de uma ideia peculiar de militância pura. Em todos os comentários a dimensão temporal da conversão opera como divisor absoluto da antítese e, mais, da assimetria dizendo no final das contas a quem o futuro pertence. Nesse sentido, a leitura de Taubés (2003) é fundamental, pois recupera nas epístolas paulinas a comunicação da Boa Nova para o povo judeu, justamente para quem a Nova não era tão boa assim, ex-povo-escolhido, povo tornado velho, Antigo. É exatamente este estrato temporal da Boa Nova que faz com que os helenos, agora pagãos, sejam coisa do passado mesmo para fins de Renascimento. A reconciliação é a Nova Aliança diante da qual as alternativas foram, historicamente, a de se converter ou a de perecer. A reconstituição da trajetória dessa antítese é importante, pois é nela que encontramos algumas metamorfoses da semântica temporal que nos coloca na encruzilhada atual, na qual é erguido o edifício etnográfico pertinente para questões de administração da diferença (REINHARDT, 2014). 
O itinerário da história da salvação oferece uma hierarquia temporalizada cujo desenho acabado é exatamente a Cidade de Deus de Santo Agostinho, em que a hierarquia estabelece o ponto de chegada, a salvação, como culminância e transcendência. E este plano é onde nunca se está, salvo quando no fim da história. O caminho da salvação passa pelo pecado, do qual nem todo mundo passa, e que introduz na antítese a espera:

Na situação concreta isto significa que, por um lado, o Império Romano foi transcendido na unidade mística da civitas terrena; ele é apenas uma articulação, se bem que particularmente grandiosa e brilhante, do pecado que reina neste mundo. Por isso a queda desse Império contém um sentido renovador, isto é, voltado para a salvação, que pode ser encontrada na civitas Dei e que os crentes têm razão de esperar, particularmente na hora da catástrofe (KOSELLECK, 2006, p. 212).

O complexo do adiamento como temporalização tem na espera pelo futuro, para onde emana a Graça, um mecanismo de temporalização que orienta a antítese, para nos determos somente nela. $\mathrm{O}$ agostinianismo político é exatamente aquele que trata a vida como sujeita ao tribunal do futuro que, com o advento das Cruzadas torna-se expansionista e mais uma vez territorializante; aterrorizante. No entanto, o território não é mais morada, mas futuro. A formação histórica dos conceitos antitéticos ao redor da humanidade universal, culminando na formação de conceitos como os de mulher, selvagem e os novos barbarismos na postulação da raça, tem um fundamento negativo particular, o da negação do poder soberano em favor da humanidade. As figuras de rejeição da autoridade política expressa na forma de principados e coroas do Iluminismo dos séculos XVII e XVIII europeus, em que a rejeição do poder de opressão culminaria no encontro do soberano com sua própria humanidade. Esta negação, cuja antítese faz do opressor tirânico a expressão da desumanidade assumirá na concorrência dos acontecimentos outras formas de manifestação em que o desafio das Américas na conquista não para de tencionar. É neste ponto que a orientação e a pesquisa de Koselleck torna-se algo decepcionante, ainda que prepare um outro terreno, temporal, para toda sorte de investigação sobre a biopolítica moderna. No entanto, o desafio americano da ordem colonial nos leva para uma paisagem em que a administração da diferença na forma da supressão temporal tem um terreno próprio. É desta ordem que trato daqui por diante, porque ela vê nascer uma determinada conformação dos fenômenos de temporalização cuja assimetria produz sua própria versão dos usos opressivos do tempo (FABIAN, 2013), para além da Europa e da antropologia disciplinar.

As antíteses para as quais prestamos atenção estão sintetizadas na seguinte passagem, escrita por Michael Taussig:

A criação da realidade colonial que ocorreu no Novo Mundo permanecerá item de imensa curiosidade e estudo - aquele Novo Mundo onde os irracionales índios e africanos se tornaram obedientes à razão de um pequeno número de cristãos brancos. Quaisquer que sejam as conclusões a que cheguemos sobre como essa hegemonia foi tão rapidamente efetuada, seria insensatez de nossa parte fazer vista grossa ao papel do terror. Com isto quero dizer que devemos pensar-através-do-terror, o que, além de ser um estado fisiológico, é também um estado social, cujos traços especiais permitem que ele sirva como mediador par excellence da hegemonia colonial: o espaço da morte onde o índio, o africano e o branco deram à luz um Novo Mundo (TAUSSIG, 1993, p. 27).

Mas é exatamente este além da Europa que figura como um embaraço na investigação dos conceitos antitéticos assimétricos. Uma vez que Koselleck ocupa-se com um projeto, para todos os efeitos, enorme, da "patogênese do mundo burguês" (1999), as assimetrias que exprimem a experiência da derrota figura formas e conceitos próprios de uma condição geopolítica que culmina na formação do Estado de Bem-Estar social, cuja forma jurídica do Estado de direito é herdeira diretamente da negação humanista dos poderes soberanos de caráter absolutista - entendendo que aí reside também a negação totalitária, onde a experiência do terror converge sua narrativa em dois episódios: a violência revolucionária e a guerra administrada pelo Estado total, 
que tem na Segunda Grande Guerra seu marco decisivo. No que tange a experiência do terror, a semântica das antíteses opera segundo uma marca distinta quando apontam para o marco temporal do Novo Mundo, uma vez que o ato de fundação do Novo Mundo opera, nos centros metropolitanos, como a elaboração lenta e gradual dos estados de exceção administrados. A correspondência entre os mundos, especialmente no que diz respeito à administração de regimes opressores do tempo, inaugurada pelas Cartas Jesuítas (EISENBERG, 2000) é real, mas apresentam notas profundamente distintas. Esta distinção é que faz com que Antônio Bispo dos Santos (2015) seja enfático, exagerado. Não são batalhas semânticas, aquelas que os povos oprimidos se inserem nos momentos de luta política. Nas antíteses assimétricas, o que está em questão são as guerras dado seu caráter perene, constitutivo da totalidade das relações e dos desdobramentos frustrantes de muitas batalhas vencidas. Aquilo que poderia sofrer rejeição da historiografia passa a ser o elemento determinante para a convivência com a experiência histórica.

Em sua investigação sobre a experiência do terror no Terceiro Reich, Koselleck confronta-se com a determinação do fato na ordem documental em que as narrativas de experiência convivem com a suspeita do exagero, da desproporção hiperbólica que hipoteticamente o discurso historiográfico deveria sanar. Trazer de volta ao documento, ao registro que fixa o conceito. Mas estamos falando justamente da experiência do terror, para a qual o caminho trilhado por Michael Taussig é justamente o da alucinação. Nesse sentido, tanto Taussig quanto Koselleck adentram na seara cibernética da memória produzindo amplificação, o que para fins de semântica temporal uma pletora de horizontes narrativos começa a tomar forma, do presságio ao xamanismo.

O terror não só provoca sonhos; os próprios sonhos fazem parte dele. As duas histórias [duas histórias da coletânea de Charlotte Beradt, Das Dritte Reich des Traumes, que Reinhart apresenta brevemente] reproduzem uma experiência que penetrou profundamente nas pessoas; contêm uma verdade interior que se realizou no Terceiro Reich e, mais do que isso, foi desmedidamente superada. Essas histórias sonhadas não só testemunham o terror de suas vítimas; hoje podemos dizer que elas constituíam um presságio. (KOSELLECK, 2006, p. 352).

O inverossímil torna-se presságio diante da catástrofe. Esta é, creio, a primeira lição a ser apreendida com Koselleck, independente da matriz histórica com a qual ele trabalha. Os sonhos durante o Reich e a supressão do tempo nos campos de concentração traduziram-se em intrincados sonhos sobre o futuro, sonhos de vigília, em presságios de sinal trocado. Viktor Frankl relata, no caso, a história de um amigo que sonhou com a data de sua libertação, data esta que se tornou a de sua morte. "A sensação de segurança da vida no lar, que parecia prometer esperança, se transformou em signo de morte" (KOSELLECK, 2006, p. 257), o que nos coloca em posição frontal com o suicídio de Walter Benjamin e o presságio da invasão nazista em Port Bou que faz do seu cadáver a mesma aporia da experiência que discutimos aqui (TAUSSIG, 2006). Ficamos de frente, também, para os relatos de terror do tratamento que os irmãos Arana impunham aos indígenas escravizados no Putumayo, entre os rios Caraparaná e Igaraparaná, cujo horror parecia um exagero - o que é uma representação? - de tão inacreditável, como se o realismo não fosse também a expressão de uma mitologia, de um conhecimento tácito (TAUSSIG, 1992). Ficamos de frente, enfim, para os relatos presentes das comunidades quilombolas que mantêm vivas as narrativas de tortura e violência improvisada dos tempos vividos por ancestrais que marcam tão vivamente a experiência do território (SANTOS, 2012). Eis a forma-limite da experiência que se torna coletiva tão presente no trabalho de Michael Taussig e o problema dos espaços de morte, dimensão extrema dos espaços de negação, de supressão temporal, isto é, da vida.

A atenção que Koselleck dá à estrutura semântica, e não à literalidade dos substantivos movidos pelos conceitos, é concretizada com precisão e poesia no Estudo sobre terror e cura de Taussig (1993). Nele vemos como a administração da diferença produz uma concepção de espaço de opressão em que a supressão do tempo toma a forma do terror permanente que nos escritos de Koselleck está circunscrita na forma de exceção e presságio. O trabalho de Taussig consegue mobilizar um enorme corpus documental, tão heterodoxo quanto 
é a inscrição das diversas formas de escritura no cotejo direto com a experiência, em que a administração da experiência enquanto colonização do espaço apresenta o esforço em tipificar as práticas de determinação do espaço de negação - espaços de morte'.

Com a conquista e a colonização europeia, esses espaços de morte se misturam em um fundo comum de significantes essenciais, ligando a cultura transformadora do conquistador à do conquistado. No entanto, os significantes estão estrategicamente deslocados em relação àquilo que eles significam. «Se a confusão é o sinal dos tempos, escreveu Artaud, vejo na raiz desta confusão uma ruptura entre coisas e mundos, entre coisas e as ideias e signos que constituem sua representação. Ele imagina se essa cisão é a responsável pela vingança das coisas; a poesia, que já não se situa mais dentro de nós e que não conseguimos mais encontrar nas coisas, surge subitamente em seu lado errado'. Marx assinalou o mesmo desarranjo e um novo arranjo entre nós e as coisas no fetichismo das mercadorias, no qual a poesia aparecia subitamente do lado errado das coisas agora animadas. Na história moderna o fetichismo das mercadorias rejuvenesce a densidade mítica do espaço de morte - graças à morte do sujeito, bem como graças à recém-descoberta arbitrariedade do signo, por meio do qual um animismo ressurgente faz com que as coisas se tornem humanas, e os humanos, coisas. É neste terror do espaço de morte que encontramos frequentemente uma exploração elaborada daquilo que Artaud e Marx, cada um a seu modo, vêem como a ruptura e a vingança da significação (TAUSSIG, 1993, p. 27).

Entendendo que "as coisas se tornam agentes de terror", impondo à cultura material uma dinâmica e uma memória muito diferentes do sincronismo das técnicas, a administração das coisas está sujeita a modos de expressão cuja semântica das antíteses mostra-se desafiadora especialmente por seu caráter normal e diluído. O comentário ao Relatório do Putumayo, escrito por Roger Casement ao Ministério das Relações Exteriores da Grã-Bretanha no dia 13 de julho de 1913 nos oferece um exercício de semântica histórica tão penetrante quanto assombrosa, isto é, pelo exército de fantasmas que convoca para distrair os passos dados pelos viventes.

Casement é um caso de um agente colonial que vivia a dialética do terror na carne. Homossexual, irlandês - "foi seu conhecimento da história irlandesa que permitiu compreender as atrocidades do Congo" (TAUSSIG, 1993, p. 39) -, reconhecia nas populações indígenas do Putumayo peruano-colombiano, um desenvolvimento moral ímpar, superior às práticas de seus colonizadores. O relatório em questão, movido pelos protestos públicos em razão da brutalidade instrumental das companhias de borracha em atividade na região, é fruto da viagem - sempre as viagens - de Casement à região, em 1910, para que investigasse, dentre outras coisas, a responsabilização do Império Britânico em um contexto de violência que muito rapidamente fora comparada com o Congo Belga do rei Leopoldo. As experiências relatadas pelo americano Walter Hardenburg, em uma série de reportagens que teciam esta comparação trazem à tona a figura de Julio César Arana, um dos irmãos Arana, proprietário de uma companhia - atravessadora - de extração de borracha. Os métodos utilizados para a administração deste sistema econômico de extração-atravessamento para exportação que caracterizam a base do sistema econômico colonial entram em questão, mais particularmente no que concerne aos conceitos antitéticos expressos pela categoria conquista. Afinal, é assim que a ascensão de Arana é sintetizada. Sua capacidade de produzir um sistema permanente de extração e distribuição de borracha é definida pela conquista. Seu derecho de conquistar, próprio da mobilização dos recursos de guerra-justa que caracteriza a colonização sul-americana como forma jurídica nos dá a entrada semântica para as práticas de comunicação que orientam as controvérsias a respeito das práticas coloniais. Afinal, o que é conquistar?

9 O espaço de morte é importante na criação do significado e da consciência, sobretudo em sociedades onde a tortura é endêmica e onde a cultura do terror floresce. Podemos pensar no espaço de morte como a soleira que permite a iluminação, bem como a extinção. De vez em quando uma pessoa a ultrapassa e volta até nós para dar seu depoimento, conforme fez [Jacobo] Timerman, que se tornou vítima da força militar que ele inicialmente apoiava e então criticou através de seu jornal La Opinión, lutando com as palavras, em meio e contra o silêncio instituído pelos árbitros do discurso, que impuseram uma nova realidade nas celas onde torturador e torturado se reuniram" (TAUSSIG, 1993, p. 26). Convém notar que a trajetória de quem atravessa a soleira não é outra que não a do xamã. Para uma discussão pormenorizada deste tema, vide CUNHA (2009). 
Sabemos que a conquista envolve as populações indígenas em um continente e em um contexto. A delimitação do território a ser administrado, imposto pela força, também implica numa dinâmica que reinveste o território de sua própria constituição. O reinvestimento, no caso de Arana, estava vinculado a uma forma de produção de dívida que faz com que a leitura maussiana sobre a dádiva recupere uma dimensão que o jusnaturalismo implícito do socialismo republicano de Mauss dificilmente permitiria antever: o da violência originária. Afinal, como seria possível produzir um sistema de escravidão pela dívida no território em que aqueles que exercem o poder majoritário são exatamente os que impõem aos povos do Putumayo o seu domínio? Os comentários de Joaquín Rocha, contemporâneo e participante do debate a respeito da noção de conquista, definem que aquele que conquista um determinado povo é aquele que consegue travar comércio, comércio este que faria acontecer à base de presentes, dívida e força. Afinal, anota Rocha, a persuasão verbal sempre se mostrou insuficiente, assim como a paisagem é sempre favorável à fuga dos povos nativos e os que, à força, tornaram-se nativos na forma de sua própria escravidão (MONTEIRO, 1995; MOURA, 1981). Daí, a conexão da conquista com a produção dos espaços de morte toma forma.

Ao perceber sinais de índios que não pertenciam a qualquer tribo conhecida, o coração do comerciante pulsou diante da ideia de conquista-los, pois, através do trabalho deles, poderia obter enormes quantidades de borracha. De madrugada, sob um luar esplêndido, os brancos entraram na casa comunitária dos índios. Dois deles bloquearam a porta com suas armas enquanto seu patrón, o comerciante, disse aos índios, tomados de pânico, que não se assustassem. Os homens foram solicitados a buscar comida que as mulheres - as quais, aliás, não tiveram permissão de sair - cozinhariam. Quando os homens regressaram, os brancos os presentearam com quinquilharias e deram-lhes roupa, machados e facões, dizendo que deveriam trazer-lhes borracha enquanto eles, os brancos, se apoderariam da casa dos indios com suas mulheres e crianças, na ausência dos homens. Felizes com os presentes e as mercadorias, os homens concordaram e voltaram daí a alguns dias com a borracha que deviam (TAUSSIG, 1993, p. 44).

A cena descrita repete-se por toda a história colonial americana a ponto de tornar-se parte de sua história natural. No entanto, é menos reificada na medida em que as narrativas afastam-se dos centros metropolitanos, tornando-se experiência vivida nos contextos da margem política, lugares em que o impacto colonial é mais perene, onde a guerra de denominações é a expressão linguística do conflito, particularmente em contextos em que as relações entre extrativismo e atravessamento para fins de distribuição que tão bem descrevem as companhias coloniais seguem orientando as práticas econômicas do território e assim, sua administração, como é o caso do sudeste do Piauí. Oferecem um contexto em que a dívida é criada a partir da criação de um problema que as populações locais não tinham, de forma a se oferecerem, as diversas agências coloniais e republicanas, como as únicas detentoras dos poderes de mediação ${ }^{10}$. O dispositivo teológico-político das profecias justifica o aparelho colonial com uma precisão e força que somente confirmam a dimensão da repetição histórica que fazem com que essa narrativa se repita em sua profunda singularidade de acontecimento, no caso, a experiência do terror e, dialeticamente, das diversas formas de compadrio que poderiam advir do advento da força. O terror como norma instaura uma relação entre opressão e desejo em que a supressão do tempo inaugura o Novo Mundo como nova emergência do Estado metropolitano, a versão da negação total que a ideia da Boa Nova jamais poderia antecipar com clareza, por mais que flertasse com esse horizonte, o do futuro absoluto da conversão que envolvia também a concorrência, exterminada sempre que possível com a mesma lógica de redução à selvageria como condição de humanidade suprimida, ou alvo de uma das várias encarnações da guerra-justa. "Este é o começo de uma bela amizade", segundo a imaginação de Gilberto Freyre cujo Casa-Grande \& Senzala não é outra coisa senão a narrativa-mestra da instituição deste enorme espaço de morte cujo apelido é Brasil. O espaço de morte, mais do que um espaço cujas narrativas

10 Eu jamais conseguiria exprimir esta fórmula sem as conversas que tenho com Antônio Bispo dos Santos, a quem agradeço da mesma forma em que me responsabilizo por um possível mau uso de uma fórmula que é ancestral, como, aliás, quase tudo o que escrevo. As remissões bibliográficas não estão aqui à toa. 
de experiência relatam a morte e a tortura a qualquer momento. A supressão do tempo em favor da reiteração da possibilidade de que a morte e a tortura podem acontecer, mais do que de forma surpreendente, como fruto de um capricho ou uma decisão banal, instaurando a suspensão do tempo como a expressão da norma somente para acelerá-lo novamente quando a administração considerar urgente. Isso faz com que os espaços de negação possam ser compreendidos como a supressão temporal em que as antinomias operam como determinação total do espaço. A administração da diferença expressa nas assimetrias semânticas tende à totalidade, e não à relação, e operando com força de lei, fazendo com que a experiência das populações administradas e suas narrativas tendam a zero em nome da constituição da territorialização da ordem. O terror, o despejo, a violação, não sendo acidentes porque parte daquilo que a administração prevê e desenha, são a própria concretização do território inaugurado pelo advento da lei, até o presente momento, supressor das diferenças que fazem da paisagem o ambiente que todavia gere.

Se é possível encontrar paralelos importantes em situações diversas e produção do território pelo prisma da administração, especialmente com relação à dialética do imobilismo burocrático e a resolução emergencial ad hoc e, frequentemente, arbitrária e violenta (ALMEIDA; OLIVEIRA FILHO, 1998; BAINES, 1990; MORAIS, 2018 $)^{11}$, a generalidade do problema, que não quero tratar como uma epidemia de violência mas como práticas governamentais, torna-se ainda mais evidente quando saímos da seara da colonização e adentramos no universo da segurança pública, isto é, urbana. A tese de Adalton Marques (2018, p. 31) parte da mesma premissa, a de que a estrutura temporal da decisão administrativa a respeito da diferença, no caso aquela que constitui a população carcerária e o problema da criminalidade, passa pelo mesmo modo de relação, ora congelado nos imobilismos estéreis, ora conduzida por medidas emergenciais cuja tipificação dispositiva obriga a sempre ser ou uma coisa, ou outra, com repertórios e lógicas exclusivas. Há toda uma tecnologia do tempo que se traduz, penso, na forma da crise persistente como prática de governo, que não poucas vezes permitem que irmanemos algumas práticas de administração prisional com outras que, em tese, tinham como horizonte outra lógica, de caráter preservacionista, ambiental, nos lembrando do enorme fosso existente entre a justificativa teórica de uma determinada política e os meios de sua administração.

Há aqui um paralelo com a história das remoções no Mato Grosso do Sul que nos ajuda a refletirmos melhor a respeito deste paralelo. Diz respeito aos meios pelos quais a população kaiowá e guarani foi reduzida em aldeamentos e, então, em reservas constituídas pelas políticas do antigo Serviço de Proteção ao Índio e Localização o Trabalhador Nacional (SPILTN), que depois se torna somente Serviço de Proteção ao Índio (SPI) -, órgão antecessor da FUNAI ${ }^{12}$. Em uma discussão travada no cone sul do Mato Grosso do Sul, assim como se dá com o sudeste do Piauí e com o Vale do São Francisco, a guerra na constituição das frentes de expansão do capital é um tema persistente. Lá e cá, a Guerra da Tríplice Aliança e a sucessão sertaneja dos conflitos em Canudos, Caldeirão e Pau de Colher (SANTOS, 2015). Se a lei de terras de 1850 que estabeleceu o regime de sesmarias excluiu expressamente as terras indígenas, a instituição do indigenato opera numa revisão da história natural em que o direito originário os localiza na terra em que ocupam. Sem qualquer

11 Convém enfatizar que esta bibliografia está longe de ser exaustiva ou meramente atualizada. Ela aponta, na verdade, para três referências bibliográficas que discutem três casos mais conhecidos do debate público brasileiro. No primeiro caso, a trajetória das políticas de demarcação de terras indígenas cujo impacto é total para a produção de uma bibliografia renovada a respeito dos conflitos agrários no que tange o reconhecimento dos direitos territoriais de populações indígenas, quilombolas e tradicionais-locais no Brasil contemporâneo. No segundo caso, a tragédia waimiri-atroari, povo de língua carib, e a construção da BR 174 (Amazonas-Roraima), tragédia que prossegue nos tempos presentes. No terceiro caso, o livro de Bruno Morais é uma publicação derradeira de uma produção corajosa e rigorosa em antropologia militante junto às populações guarani que conta com produções como as de Tonico Benites, Antonio Brand, Bartommeu Meliá, Pierre Clastres, Helène Clastres, Maria Inês Ladeira, Fábio Mura, João Izaque, Francisco Noelli, Daniel Pierri, Spensy Pimentel e Lauriene Seraguza. Aqui aponto alguns nomes pertinentes somente para o campo genérico guarani e kaiowá, muito mais específico e complexo do que eu poderia dar conta. Cada uma dessas remissões merecem atenção específica, convindo lembrar que uma pletora de outros eventos administrativos poderiam ser remetidos a bibliografias específicas, como a diversidade dos sistemas prisionais e os arranjos carcerários (Karina Biondi e Fabio Mallart) e as dimensões das grandes obras de grande aparato administrativo como Belo Monte (Thaís Mantovanelli, Bel Juruna). Em cada um deles seria possível reverberar enunciados pertinentes à questões postas aqui, o que é uma outra forma de dizer o tamanho da dívida que tenho com esta produção bibliográfica que, seguramente, merece maior atenção da investigação não-especialista.

12 Até 1928 eram 8 Reservas Indígenas no Mato Grosso do Sul, todas demarcadas a partir de 1915 (MORAIS, 2018, p. 79; fonte: FUNAI, IBGE, ANA e Ministério dos Transportes). 
consideração a respeito dos modos de ocupação, ou sobre modificações de caráter demográfico ou mesmo uma levantamento apurado que pudesse orientar a melhor regulamentação do regulamento da Lei de Terras, é o aldeamento, a ordem do confinamento indígena em terras demarcadas que impera com a finalidade da "colonisação (sic) de indígenas" (MORAIS, 2018, p. 73, nota 13). A presença da monocultura de mate, capitaneada pelo monopólio da Companhia Matte Larangeiras, tornou a presença indígena ainda mais difusa e complexa na medida em que, seja pelo trabalho escravo, seja pela exploração e abuso, produzissem um esparramo (sarambi, em guarani) das antigas aldeias promovendo movimentos forçados de aldeamento em reservas. As expulsões contaminam todo o século XX com sucessivos arranjos administrativos, do período Vargas até os tempos do monocultivo da soja de então.

o alcance da destruição das aldeias e das remoções forçadas estão profundamente marcadas na memória dos que foram expulsos de suas terras, sobretudo entre os anos 1940 e 1970; no entanto, despejos de aldeias não só ainda acontecem no Mato Grosso do Sul como as famílias das reservas, sem condições de se firmar em lugares demarcados pelo Estado, se veem obrigadas cotidianamente a romper os seus vínculos e a dispersar os seus fogos domésticos em busca de um lugar onde a vida seja viável (MORAIS, 2018, p. 112).

A inviabilidade da morada imposta pelo cerco que a legislação a respeito das reservas impõe oferece um nível de analogia importante sobre a generalidade da administração da diferença pautada no cercamento. Mas os registros de Levi Marques Pereira para a Comissão Nacional da Verdade mostram o tipo de operação que envolve a administração dos corpos guarani em práticas de remoção, no caso, os a aldeia Takuara e que foram devidamente indenizados segundo a $5^{a}$ Inspetoria Regional do SPI. Sua remoção para a Reserva o Caarapó é reconstituída pelos mais velhos de outra forma: correria, confusão, casas queimadas, pessoas amarrada e colocadas à força em carroceria de caminhão; dias depois, dois corpos foram encontrados, carbonizados, em uma casa queimada pelo SPI - uma anciã e uma criança, uma das duas mortas no episódio, sendo a segunda tendo morrido afogada no rio Taquara durante a fuga (MORAIS, 2018, p. 86). Oficialmente, para fins administrativos, o registro que temos é tão só e simplesmente remoção indenizada. Isto nos leva de volta para o Antigo Zabelê.

\section{De volta ao Piauí pela primeira vez}

Era 1962. Gaspar Ferreira, pai do atual secretário de ciências e tecnologia do estado do Piauí, Avelar Ferreira, foi a São Paulo. Na época, Gaspar era prefeito de São Raimundo Nonato e visitou o Museu do Ipiranga. Nilson me conta que ele viu uma pintura rupestre tal como aquela que ele tinha visto na região próxima de Várzea Grande. Imediatamente Gaspar informou a direção do Museu a respeito as pinturas que tinha visto com seu amigo Nilson. Meses depois Gaspar enviou fotografias das imagens similares às que tinha visto no Museu, então dispostas na paisagem do semi-árido piauiense. Essas fotografias enviadas para o Museu foram tiradas por Fernando Galvão, que só chegou ao local porque Nilson Parente, caçador de onças renomado, lhe guiou. É Nilson quem me conta esta história em 08 de julho de 2018, na porta de sua casa, no povoado no Novo Zabelê, assentamento rural à beira da estrada PI-141, a $10 \mathrm{~km}$ do perímetro urbano de São Raimundo Nonato. Fui conduzido até ele por um aluno do curso de arqueologia, Maharany Timóteo, com quem venho trabalhando desde então.

Em setembro de 1970, em 2 de setembro, me dizia Nilson fazendo um esforço de precisão quase sempre recompensado pela aparição das datas, Niéde veio a São Raimundo Nonato para conversar com o mesmo Gaspar Ferreira. Era a primeira vez em que visitava a região. Nesta conversa, ela teria ouvido falar de Nilson, com quem foi se encontrar na barragem do Antigo Zabelê. No dia 04 ambos, Nilson e Niéde, singraram o sertão próximo para mostrar as imagens que tinham sido fotografadas. Um rapaz de quem Nilson não disse o nome ficou enquanto Niéde foi para a França. No semestre em que ela fica fora do país, tendo voltado em fevereiro de 1971, Nilson e o rapaz registram 70 tocas como aquelas que foram preservadas no movimento que 
acabou por derrubar as moradas do Antigo Zabelê, removendo 602 descendentes do fundador do povoado, compreendendo as famílias Paes Landim, Miranda e Parente. Eram 70 casas que, a esta altura, desconfio, pareiam com as 70 tocas registradas por Nilson e o rapaz que ficou quando Niéde Guidon partiu pela primeira vez. Afinal, o povoado do Zabelê tinha duas moradas: uma para o inverno no povoado que discutimos aqui, e as tocas ao redor do Olho D’Água no período da estiagem. Mas não sei dizer ao certo.

Fundado em 1884 por Marco Fava Seca - Nilson jamais me disse o nome de batismo, que intuo ser Marco Parente -, o povoado do Zabelê foi fundado no mesmo movimento de maniçobeiros que mobilizou parte da economia piauiense em ciclos intermitentes da borracha. Rodeando o baixão onde fez sua roça, Marco Fava Seca repete aqui o padrão fundiário dos posseiros sertão afora, numa "fazenda sem divisão" que a literatura antropológica reconhece com uma pletora de nomes: terra de conjunto, terra de ausente, terra de santo, terra de padroeiro, fundo de pasto, terra de preto etc. Filho de Florêncio Parente, tataraneto de Marco Fava Seca, Nilson nasceu já em 1935, em um 7 de janeiro. Ouvindo rádio pela primeira vez em 1942, as proezas de Nilson como guia são na verdade um desdobramento daquela que foi sua principal atividade durante boa parte de sua vida. Nilson, como já disse, caçava onças. Pelas suas contas, 73, não contando uma que ele capturou no laço com seu irmão Quelé mais um cachorro bom de onça. A caça é uma arte da necessidade, o elemento essencial para que possamos compreender a razão de se trilhar tantos "carreiros" caatinga adentro por dias, meses, fazendo de caçadores e vaqueiros as figuras emblemáticas da paisagem, a imagem do catingueiro. A atividade econômica matriz, da extração de maniçoba e do gado à caça do tatu e da onça, todas ilegais imediatamente após o decreto presidencial de 1979. Antes da remoção, a ilegalidade e a história do parque enroscam. Eles, que não sabiam o que era o parque, já eram, em sua maioria, ilegais e removíveis. A notícia sobre o parque futuro chega já na forma de decreto. A conversa primeira é a de cercamento, proteção e manutenção de todos os viventes, e os exemplos das reservas kaiowá e guarani nos mostram que isso pode significar todo tipo de coisa. Cristina Pompa registra esse mesmo movimento, o a intenção original de manter o povoado do Zabelê envolvidos pelo parque (1987). Mas o vento muda de direção, como já sabemos, ainda que não, eu não saiba a razão. O povoado do Zabelê é removido em 1986 com pagamento somente parcial das indenizações, sem que houvesse qualquer esforço para o reassentamento das 602 descendentes de Marco Fava Seca. Em 2018 comemoram-se os 30 anos da constituição cidadã e da derrubada das casas do povoado. Nisso, existem duas coisas salientadas por Nilson diversas vezes, coisas que Nilson repete tanto quanto possível: Niéde Guidon fez os primeiros desenhos de reprodução das pinturas rupestres, ainda na toca do Mulungú, montada em seus ombros e que ele mesmo não tem nenhum problema com ela, que o pagou por todos os trabalhos que realizou para ela. Direitinho. O problema todo é o parque, pois a história do parque é a história do Zabelê.

\section{Bibliografia}

AGAMBEN, Giorgio. Homo sacer: o poder soberano e a vida nua I. Tradução de Henrique Burigo Belo Horizonte: UFMG. 2007

BAINES, Stephen G. "É a FUNAI que sabe": a frente de atração waimiri-atroari. Belém: MPEG/CNPq/SCT/PR. 1990 BENJAMIN, Walter. Obras escolhidas: magia, técnica, arte e política. Tradução de Sergio Paulo Rouanet. São Paulo: Brasiliense. 1994

O anjo da história. Organização e tradução de João Barrento. Belo Horizonte: Autêntica. 2013

BÍBLIA. Bíblia de Jerusalém. São Paulo: Paulus. 2002

CUNHA, Manuela Carneiro. Xamanismo e tradução. In: CUNHA, M. Cultura com aspas e outros ensaios. São Paulo: Cosac \& Naify. 2009.

EISENBERG, José. As missões jesuítas e o pensamento político moderno: encontros culturais, aventuras teóricas. Belo Horizonte: UFMG. 2000.

ESPOSITO, Roberto. Bios: biopolítica e filosofia. Wander Melo Miranda. Belo Horizonte: UFMG. 2017

FABIAN, Johannes. Language and colonial power: the appropriation of swahili in the former Belgian Congo 18801938. Berkeley: University of California Press. 1986.

FABIAN, Johannes. Presence and representation: the Other and anthropological writing. Critical Inquiry, vol. 16. 
No.5. p. 753-772. Verão de 1990

FABIAN, Johannes. O tempo e o outro: como a antropologia estabelece seu objeto. Petrópolis: Vozes. 2013.

FLUSSER, Vilém. O mundo codificado: por uma filosofia do design e da comunicação. Tradução de Raquel Abi-Sâmara. São Paulo: Cosac \& Naify. 2007.

FREIRE, Bernardo Curvelano. Questões postas ao território: mineração e comunidades produtoras em São Raimundo Nonato. In: MARISY, Lúcia (org.) Sem título. Curitiba: UNIVASF/CRV. 2018 (no prelo)

GODOI, Emilia Pietrafesa de. O trabalho da memória: cotidiano e história no sertão do Piauí. Campinas: Unicamp. 1999.

GOULD, Stephen Jay. Seta do tempo, ciclo do tempo: mito e metáfora na descoberta do tempo geológico. Tradução de Carlos Afonso Malferrari. São Paulo: Companhia das Letras. 1991.

GUIDON, Niéde. Potencialidades dos eco-sistemas e complexidade social: aplicação no estudo da pré-história do nordeste. Revista de Antropologia (volumes 30/31/32). FFLCH/USP. São Paulo. 1987/1988/1989.

As ocupações pré-históricas do Brasil (excetuando a Amazônia) In: CUNHA, Manuela Carneiro (org.) História dos índios no Brasil. São Paulo: Companhia das Letras. 1992.

HARDT, Michael; NEGRI, Antonio. Império. Rio de Janeiro: Record. 2001.

KOYRÉ, Alexandre. Do mundo fechado ao universo infinito. Tradução de Ronaldson M. Garschagen. Rio de Janeiro: Forense Universitária. 1979.

KOSELLECK, Reinhart. Crítica e crise: uma contribuição à patogênese do mundo burguês. Tradução de Luciana Villas-Boas Castello Branco. Rio de Janeiro: EdUERJ/Contraponto. 1999.

Futuro passado: contribuição à semântica dos tempos históricos. Tradução de Wilma Patrícia Mass e Carlos Almeida Pereira. Rio de Janeiro: Contraponto/PUC Rio. 2006.

Estratos do tempo: estudos sobre história. Tradução de Markus Hediger. Rio de Janeiro: Contraponto/PUC Rio. 2014.

MARQUES, Adalton. Humanizar e expandir: uma genealogia da segurança pública em São Paulo. São Paulo: IBCCRIM. 2018.

MARTIN, Gabriela Pré-história no nordeste do Brasil. Recife: UFPE, 2013.

MONTEIRO, John Manuel. Negros da terra: índios e bandeirantes nas origens de São Paulo. São Paulo: Companhia das Letras. 1995.

MORAIS, Bruno Martins. Do corpo ao pó: crônicas da territorialidade kaiowá e guarani nas adjacências da morte. São Paulo: Elefante/ANPOCS, 2017.

MOURA, Clovis. Rebeliões da senzala. São Paulo: Livraria Editora Ciências Humanas, 1981.

OLIVEIRA, João Pacheco; ALMEIDA, Alfredo Wagner Berno de. Demarcação e reafirmação étnica: um ensaio sobre a FUNAI. In: OLIVEIRA, João Pacheco de (org.). Indigenismo e territorialização: poderes, rotinas e saberes coloniais no Brasil contemporâneo. Rio de Janeiro: ContraCapa, 1998.

POMPA, Maria Cristina. O Parque Nacional Serra da Capivara: um drama social. (mimeo) 1987.

REINHARDT, Bruno. Poder, história e coetaneidade: os lugares do colonialismo na antropologia sobre a África. Revista de Antropologia, São Paulo: USP. v. 57, n. 2, p. 329-375. dezembro, 2014

ROSSI, Paolo. Os sinais do tempo: história da Terra e história das nações, de Hooke a Vico. Tradução de Julia Mainardi. São Paulo: Companhia das Letras, 1992.

SANTOS, Antônio Bispo dos. Colonização, quilombos: modos e significações. Brasília: INCTI, 2015.

SANTOS, Carlos Alexandre Barboza Plínio “Negros do Tapuio”: memórias de quilombolas do sertão piauiense. Curitiba: Appris, 2012.

TAUSSIG, Michael. History as sorcery. Representations, n. 7, p. 87-109. Verão, 1984.

. Xamanismo, colonialismo e o homem selvagem: um estudo sobre o terror e a cura. Tradução de Carlos Eugênio Marcondes de Moura. São Paulo: Paz e Terra, 1993.

Walter Benjamin's grave. Chicago: Chicago University Press, 2006.

VELHO, Otávio. Capitalismo autoritário e campesinato (um estudo comparativo a partir da fronteira em movimento). São Paulo: Difel, 1976.

VIVEIROS DE CASTRO, Eduardo. Filiação intensiva e aliança demoníaca. Novos Estudos- Cebrap, 77. pg. 91-126. São Paulo: Cebrap, 2007. 